\title{
Liquid biopsies in patients with diffuse glioma
}

\author{
Myron G. Best • Nik Sol • Sebastiaan Zijl • \\ Jaap C. Reijneveld • Pieter Wesseling • \\ Thomas Wurdinger
}

Received: 15 December 2014 / Revised: 11 February 2015 / Accepted: 13 February 2015 / Published online: 27 February 2015

(C) The Author(s) 2015. This article is published with open access at Springerlink.com

\begin{abstract}
Diffuse gliomas are the most common malignant primary tumors of the central nervous system. Like other neoplasms, these gliomas release molecular information into the circulation. Tumor-derived biomarkers include proteins, nucleic acids, and tumor-derived extracellular vesicles that accumulate in plasma, serum, blood platelets, urine and/or cerebrospinal fluid. Recently, also circulating tumor cells have been identified in the blood of glioma patients. Circulating molecules, vesicles, platelets, and cells may be useful as easily accessible diagnostic, prognostic and/or predictive biomarkers to guide patient management. Thereby, this approach may help to circumvent problems related to tumor heterogeneity and sampling error at the time of diagnosis. Also, liquid biopsies may allow for serial monitoring of treatment responses and of changes in the molecular characteristics of gliomas over time. In this review, we summarize the
\end{abstract}

Electronic supplementary material The online version of this article (doi:10.1007/s00401-015-1399-y) contains supplementary material, which is available to authorized users.

M. G. Best · N. Sol · S. Zijl · J. C. Reijneveld · P. Wesseling ·

T. Wurdinger $(\square)$

Neuro-oncology Research Group, VU University Medical Center, Cancer Center Amsterdam, CCA Room 3.20, Boelelaan 1117, 1081 HV Amsterdam, The Netherlands

e-mail: t.wurdinger@vumc.nl

M. G. Best · T. Wurdinger

Department of Neurosurgery, VU University Medical Center,

Cancer Center Amsterdam, Amsterdam, The Netherlands

M. G. Best $\cdot$ P. Wesseling

Department of Pathology, VU University Medical Center, Cancer

Center Amsterdam, Amsterdam, The Netherlands literature on blood-based biomarkers and their potential value for improving the management of patients with a diffuse glioma. Incorporation of the study of circulating molecular biomarkers in clinical trials is essential for further assessment of the potential of liquid biopsies in this context.

Keywords Malignant glioma $\cdot$ Minimally invasive biomarkers $\cdot$ Liquid biopsies $\cdot$ Molecular diagnostics

\section{Introduction}

Diffuse gliomas are the most frequent primary malignant tumors of the central nervous system [182]. Each year in the United States, approximately 17,000 patients are diagnosed with a diffuse glioma [119]. Nowadays, magnetic resonance (MR) imaging is the principal imaging modality for patients with suspected brain lesions [123]. For a definitive diagnosis of tumor type and malignancy grade, tumor tissue (obtained via biopsy or resection) is required [99]. Both low- and high-grade malignant diffuse gliomas

N. Sol · J. C. Reijneveld

Department of Neurology, VU University Medical Center, Cancer Center Amsterdam, Amsterdam, The Netherlands

P. Wesseling

Department of Pathology, Radboud University Medical Center, Nijmegen, The Netherlands

T. Wurdinger

Department of Neurology, Massachusetts General Hospital, Harvard Medical School, Boston, MA, USA

T. Wurdinger thromboDx BV, Amsterdam, The Netherlands 
are characterized by extensive, infiltrative growth in the brain parenchyma, rendering complete resection of the tumor impossible [36]. Even with the current standard treatment consisting of (combinations of) surgery, temozolomide (TMZ) - or procarbazine-lomustine-vincristine (PCV)-based chemotherapy-and radiotherapy [159, 160], glioma patients still face a poor prognosis. In general, the median survival of low-grade glioma (LGG; WHO grade II) patients is $5-10$ years, 3 to more than 10 years for WHO grade III oligodendrogliomas, 2 years for WHO grade III astrocytomas, and 12-18 months for WHO grade IV gliomas/glioblastomas [133]. Bailey and Cushing proposed the first systematic and detailed classification of gliomas in 1926 [7]. In the course of the following decades, the morphological diagnosis (typing and grading) of these tumors was further refined, culminating in the most recent, i.e., 2007 World Health Organization (WHO) classification of diffuse gliomas [101]. Meanwhile, it is now fully clear that for optimal management of patients with a diffuse glioma more precise classification of these tumors is needed, and that molecular markers hold great promise in this respect [100, 108, 118, 170, 179, 180]. For instance, it has become clear that patients with grade III $1 \mathrm{p} / 19 \mathrm{q}$ codeleted anaplastic oligodendrogliomas generally have a better prognosis than patients with other grade III glioma subtypes and that $I D H I$ mutant (secondary) glioblastomas tend to have a better outcome than $I D H I$ wild-type grade III astrocytomas [164].

Biomarkers are defined here as objectively measurable parameters that have additional (diagnostic, prognostic, predictive and/or monitoring) value to clinical parameters such as tumor type and grade, age, and performance status [81, 109, 133]. Detection of molecular glioma biomarkers such as MGMT promoter methylation, IDHI/IDH2 mutation, $1 \mathrm{p} / 19 \mathrm{q}$ co-deletion, epidermal growth factor receptor (EGFR) amplification and EGFR variant III (EGFRvIII) expression in tumor tissue is increasingly being used in clinical care $[64,70,183]$. For example, $1 p / 19 q$ co-deletion in diffuse gliomas serves as a diagnostic, prognostic, and predictive biomarker (indicating resp. the diagnosis of oligodendroglioma, improved survival and improved response to first-line PCV chemotherapy and radiation) [166]. New insights into gliomagenesis $[22,121,169]$ such as the potential role of glioma stem-like cells [154], intratumoral heterogeneity $[122,156]$ and molecular subtypes $[125,161,174]$ have revealed novel potential therapeutic targets. Examples are vascular endothelial growth factor (VEGF) which can be targeted by the monoclonal antibody bevacizumab, IDH1/IDH2 mutations and the development of the specific inhibitor AGI-5198, and EGFRvIII with the peptide vaccine rindopepimut $[6,35,57,135]$. Also, mutated $I D H 1$ has been reported as a marker indicating that more radical surgical glioma resection may be of benefit for the patient [14].
Non-small cell lung cancer and melanoma are at the forefront of molecular diagnostics, with a variety of treatments targeting molecular alterations defining specific cancer subtypes (e.g., BRAF, EGFR, $A L K$ alterations). Accurate molecular diagnostics is essential for personalized therapies to assess patient candidacy for a particular therapy based on drug-sensitizing genetic alterations of the tumor. These specific genetic pathway alterations that are the target of a drug are regarded as molecular companion diagnostic biomarkers. The FDA has issued guidelines stating that they will only review such targeted drugs for approval in the context of corresponding in vitro companion diagnostics [146]. Companion diagnostics for targeted cancer treatments simplifies the drug discovery process, makes clinical trials more efficient and informative, and can be used to individualize the therapy of cancer patients. There is an urgent need to develop molecular diagnostics to better identify the patients that respond to expensive targeted therapies. Currently, mutational profiles of cancer patients are determined in tumor tissues. Examples are the Cobas 4800 BRAF V600 Mutation Test (Roche Molecular Systems Inc.) which detects the BRAF V600E mutation in formalin-fixed, paraffin-embedded (FFPE) human melanoma tissue and the Vysis ALK Break Apart FISH Probe Kit (Abbott Molecular Inc.), which detects rearrangements involving the $A L K$ gene via fluorescence in situ hybridization (FISH) in FFPE tissue. However, limited access to serial tumor biopsies constitutes a major shortcoming in longitudinal molecular monitoring of targeted treatment. In addition, molecular diagnostics based on analysis of biopsied or surgically resected tumor tissue is hampered by sampling error. Many types of cancer, including melanoma, non-small cell lung cancer, and in particular glioma, have demonstrated to be of heterogeneous nature [156]. Glioma tissue heterogeneity may confound assessment of molecular markers such as EGFRvIII expression and MGMT promoter methylation. Such molecular diagnostic problems could be solved by minimally invasive techniques, possibly via advanced imaging modalities $[9,172]$ or 'liquid biopsies' $[40,66,72,88,129,137,155$, 168]. Additionally, liquid biopsies might allow for faster and more accurate tumor diagnosis of difficult-to-diagnose patients, e.g., patients presenting with a ring-enhancing lesion in the brain as measured by MR imaging that can be diagnosed as either a metastasized solid tumor or a primary brain tumor [26]. On top, molecular markers obtained via liquid biopsies may allow for repeated assessment of molecular aberrations of the tumor and real-time treatment monitoring in patients with diffuse glioma.

Importantly, whereas pathologists in conjunction with clinical geneticists are in the midst of a transformation towards molecular cancer diagnostics, the field of bloodbased cancer analysis is still awaiting such a full transformation. Blood-based analysis, historically often positioned 
Fig. 1 Overview of biomarker release, collection and assessment. In (glial) tumors, both neoplastic cells and the tumormicroenvironment release biomolecules in the circulation, either as circulating proteins (CP), circulating nucleic acids (CNA), or even complete circulating tumor cells (CTC). Blood plasma and serum are a source of circulating tumor DNA (ctDNA), circulating microRNAs (miRNAs) and circulating proteins. From whole blood, also extracellular vesicles (EVs), platelets (which internalize EVs) or complete CTCs can be isolated and used as potential biosources. These five biosources provide proteins, miRNAs, messenger RNAs (mRNA) non-coding RNAs (ncRNA) and ctDNA biomolecules (see separate lower right table). Of note, in the lower right table only biomolecules that were already identified in the particular biosources in patients with diffuse glioma are marked. These biomolecules and cells can be collected from a routinely obtained peripheral blood sample and used for further analyses in the laboratory

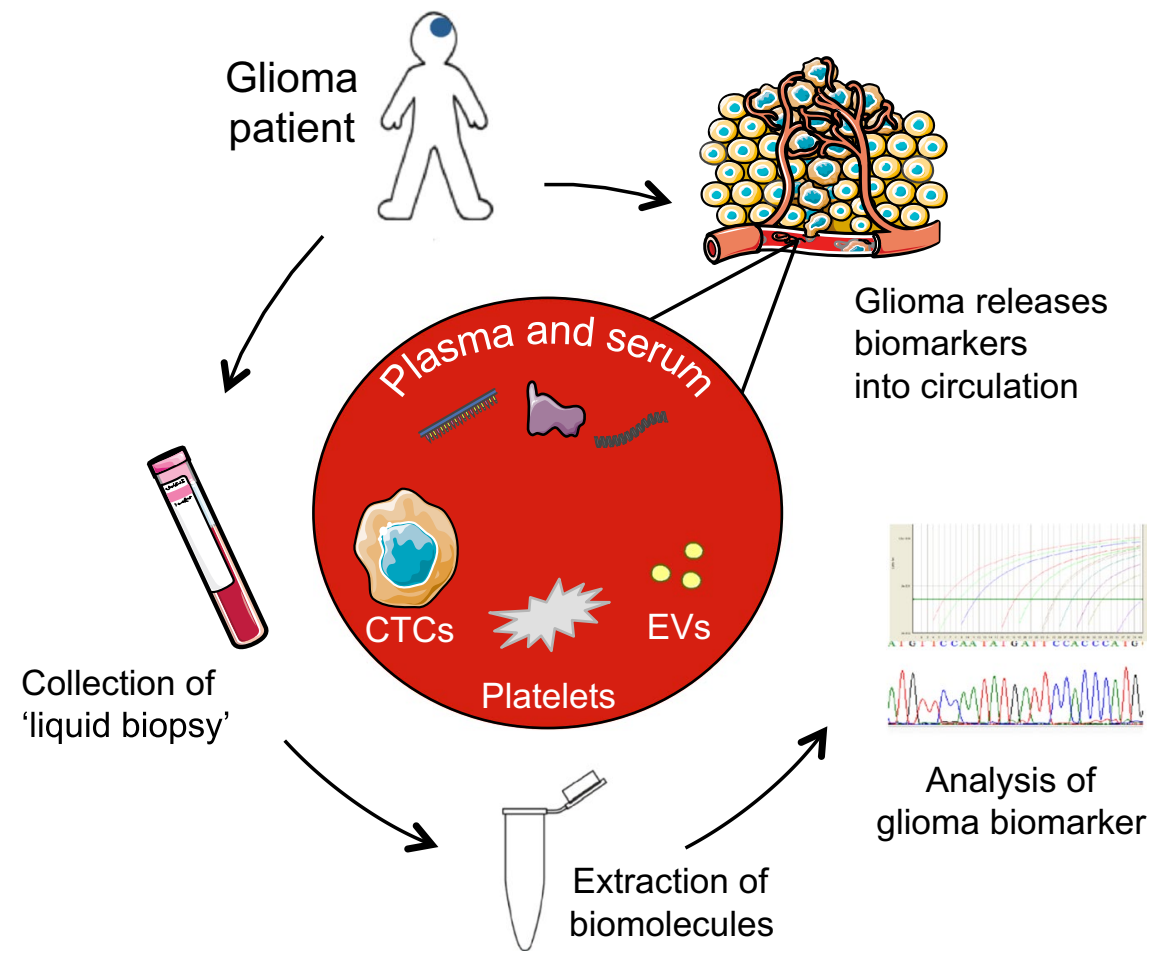

\begin{tabular}{|c|c|c|c|c|c|c|c|c|c|}
\hline & Rinm & cمانوم & & & & Proteir & & ucleic ac & \\
\hline & DIUIT & cules & & & & & miRNA & mRNA & ctDNA \\
\hline & & & & & Plasma & $\mathrm{x}$ & $x$ & & $\mathrm{x}$ \\
\hline & & & & & Serum & $x$ & $x$ & & $\mathrm{x}$ \\
\hline & & & & 总 & EVs & $\mathrm{x}$ & $\mathrm{x}$ & $x$ & \\
\hline Protein & ctDNA & mRNA & MIRINA/ &.$\frac{\circ}{m}$ & Platelets & & & $\mathrm{x}$ & \\
\hline & & & & & CTCs & $\mathrm{x}$ & & $x$ & \\
\hline
\end{tabular}

at the departments of clinical chemistry and microbiology, may likely benefit from a repositioning within the medical disciplines involved. In practice, the optimal development of diagnostics based on liquid biopsies-defined here as biofluids used for molecular diagnostics-will require next-level interdisciplinary action of clinical chemists, clinical geneticists, microbiologists, and (molecular) pathologists, among others. In this review on liquid biopsies in patients with diffuse glioma, we provide a concise discussion of the current state of the art of five blood-based liquid biopsy biosources [plasma; serum; extracellular vesicles; blood platelets (thrombocytes); circulating tumor cells (CTCs)], followed by a more elaborate discussion regarding the potential of detecting circulating proteins, circulating nucleic acids (DNA, different forms of RNA) and of circulating tumor cells.

\section{Biosources in liquid biopsies for molecular markers}

Plasma and serum are collected from whole blood and are the most studied biosources for molecular markers
(Fig. 1). Circulating tumor DNA (ctDNA) and microRNAs (miRNAs) are relatively stable in plasma and serum, as opposed to messenger (mRNA) that is easily degraded. Nevertheless, within several hours of release ctDNA is removed from the circulation by the liver and the kidneys [149]. Plasma and serum also contain extracellular vesicles (EVs), which are small lipid membrane-bound satchels expelled by cells to mediate cell-to-cell communication and containing a wide collection of nucleic acids, lipids, and proteins [4, 43, 54, 155]. The physical structure of EVs protects nucleic acids from degradation by circulating nucleases [92, 155]. Indeed, isolation of RNA from serumderived EVs from patients with glioblastoma can yield a $60 \times$ greater concentration of RNA compared to free-circulating RNA from whole blood, plasma or serum [30], which makes EVs a promising source for circulating RNA biomarkers. Complementary, circulating platelets are supplied by gliomas with tumor-derived EVs and contain tumorderived RNA [116]. Interestingly, the majority of EVs circulating in blood are also derived from platelets, suggesting that platelets efficiently sequester and release EVs [134, 187]. Similar to EVs, internalized nucleic acids in 
platelets are protected from endogenous nucleases. Finally, CTCs, although widely studied for many solid tumors [87], were only recently detected in the blood of patients with glioma [104, 113, 162]. The origin of circulating biomarkers, either directly derived from glioma cells or indirectly released by cells in the tumor microenvironment, such as inflammatory, endothelial and stromal cells, or at more distant sites like the bone marrow, is not known for all molecular biomarkers. Obviously, EGFRvIII and IDH mutant proteins or nucleic acids are released primarily by glioma cells, whereas potential biomarkers such as VEGF can be derived from multiple cell types. Also, both active secretion and passive release are possible routes for biomolecules to enter the circulation, e.g., via apoptotic or necrotic tumor or tumor-infiltrating cells $[40,149]$. In this review, cerebrospinal fluid (CSF) and urine are more marginally discussed as alternative biosources. As brain tumors are located intracranially and the brain is surrounded by CSF, this fluid may be an additional attractive liquid biopsy biosource for glioma [132]. Several studies have shown the suitability of detecting tumor-derived circulating nucleic acids [1, 10, 32, 132] and proteins $[51,53,69,83,89,90,97,115,124,142-144$, $148,153,189,191,194]$ in CSF. However, collecting CSF is a more invasive, and burdensome procedure that harbors risks, particularly the risk of brain herniation in subjects with intracranial space-occupying lesions. Biomarkers can be either directly released into the CSF or accumulate via the brain interstitial fluid and perivascular drainage system into the cerebrospinal fluid [23, 41, 75]. Possibly, potential biomarkers in CSF also end up like a 'sink effect' in the circulating blood [92].

The individual candidate biomarkers are discussed below in order of biomarker class, i.e., circulating proteins (CPs) or circulating nucleic acids (CNAs), and further subclassified according to biomarker type (diagnostic, prognostic, predictive, monitoring). The biofluids, biosources, biomarker classes, and biomarker types suitable for liquid biopsies are summarized in Fig. 1. Moreover, we discuss current and future issues which may benefit from assessment of circulating biomarkers and lead to improved clinical care for patients with diffuse glioma.

\section{Circulating proteins (CPs)}

Under several pathological conditions including cancer, the secretion, shedding and/or loss of proteins can become differentially regulated and subsequently result in increased or decreased levels of circulating proteins $(\mathrm{CP})$ in blood, urine and/or CSF [17, 185]. The majority of studies concerning protein markers is performed on blood [number of studies $(n)=29$ for plasma, and $n=40$ for serum], although also $\operatorname{CSF}(n=19)$ and urine $(n=4)$ have been reported as biosources for CPs in these patients as well. In bloodbased glioma biomarker discovery studies, proteins are so far the most extensively studied biomolecules (summarized in Supplementary Table 1). The majority of these reports is of an exploratory nature and most molecules have not yet been evaluated in large clinical trials.

Diagnostic circulating protein markers

First attempts to detect $\mathrm{CP}$ markers in blood of patients with glioma resulted predominantly in the identification of markers differentially expressed between patients and healthy controls. Plasma- and serum-derived protein markers-such as immunosuppressive acidic protein, alpha-1 acidic glycoprotein and alpha- 1 antitrypsin, the glycoprotein fibronectin, and the endothelial cell-derived thrombomodulin-1-were the first proteins to be found elevated in the blood of patients with glioma [84, 110, 141, 145], followed by protein markers related to angiogenesis in gliomas. The serum and plasma protein levels of the marker VEGF have often been reported as significantly increased in patients with glioma compared to healthy controls $[2,28$, $37,128,131]$, and even higher in patients with metastatic brain lesions [71, 128]. Soluble VEGFR-1 (sVEGFR-1), but not sVEGFR-2, -3 , and basic fibroblast growth factor (bFGF, alternatively known as FGF-2), have been reported to be increased in pre-operatively collected serum samples from newly diagnosed glioblastoma patients [39, 131]. Also, markers involved in tumor cell invasion and remodeling of extracellular matrix, such as matrix metalloproteinases (MMPs) and tissue inhibitors of metalloproteinases (TIMPs), were identified as potential diagnostic CP biomarkers. Increased levels of MMP-2 and 9 were observed in CSF of high-grade glioma patients [51], and a larger study confirmed increased plasma levels of MMP-9 and TIMP-1 in patients with both grade II and IV glioma compared to healthy controls [95]. Surprisingly, however, in this study no difference was observed in the plasma protein levels of MMP-9 and TIMP-1 of grade III glioma patients as compared to healthy controls. Serum and plasma levels of TIMP-1 allowed the discrimination of grade IV from lower grade gliomas, and were confirmed in two additional studies [39, 95, 155, 157]. Furthermore, glial fibrillary acidic protein (GFAP) was suggested to have diagnostic value $[24,68,73,80,102]$. An increase of circulating GFAP levels was observed in pre-operatively collected samples from grade III and IV glioma patients in both serum and plasma $[68,73]$. Also in a subset of patients with oligodendroglial tumors, high levels of GFAP were found in plasma, implying that circulating GFAP is not specific for high-grade malignant astrocytic neoplasms [68]. Of interest, in patients with multiple sclerosis or a metastatic brain lesion, plasma GFAP levels were found to be within 
the reference range [73, 102]. Plasma GFAP may, together with plasma placental growth factor (PIGF), differentiate between radiologically suspected high-grade glioma and brain metastases [73]. Obviously, the fact that not only GFAP, but also other markers such as brain-derived neurotrophic factor (BDNF) and S100 calcium binding protein B (S100B), can be detected in the circulation of healthy controls negatively influences the specificity of such protein markers for detection of disease processes [91]. Finally, urine protein levels of 2-hydroxyglutarate (2-HG) may aid in distinguishing $I D H 1$ mutant glioma patients from those with $I D H 1$ wild-type glioma [98]. Assessment of the 2-HG metabolite in pre-operatively collected serum samples did not allow for such discrimination [27]. Potential diagnostic value has also been reported for serum and/or plasma levels of EGFR protein [127, 151], transforming growth factor beta (TGFb) [147], tumor necrosis factor alpha (TNFa) [2, 28, 59, 131], interleukin 2 (IL-2) and its receptor [59, 192], Chitinase-3-like protein 1 (CHI3L1, also known as YKL40) $[15,167]$, S100B [73, 102, 175], neural cell adhesion molecule (NCAM) [171], neuropeptide Y (NPY) [73] and BDNF [73].

\section{Prognostic circulating protein biomarkers}

CP markers with prognostic value can be subdivided in two subgroups; tumor-related markers and markers associated with endogenous systemic stress responses. The glioma-related serum and plasma markers YKL-40, osteopontin (OPN) and the extracellular domain of EGFR were described to be inversely correlated with overall survival [15, 63, 67, 77, 127, 157]. Interestingly, increased serum levels of YKL-40 1 week after surgery and during followup of glioma patients, both newly diagnosed and recurrent, were associated with increased risk of death, also when adjusted for age, Karnofsky performance scale (KPS) and extent of surgical resection [15, 67, 77]. Furthermore, serum levels of YKL-40 appeared to be relatively stable over time [167]. In patients with recurrent glioblastoma prior to treatment with a combination of the monoclonal antibody bevacizumab and the topoisomerase 1 inhibitor irinotecan, elevated plasma levels of MMP-2 and decreased plasma levels of MMP-9 were associated with increased overall survival (OS) [165]. In addition, many CP markers implicated in tumor angiogenesis are associated with the survival of patients with glioma. The plasma levels of IGFBP-2 and VEGF, the serum level of plasminogen activator inhibitor-1 (PAI-1), and the CSF protein levels of hepatocyte growth factor (HGF), bFGF and VEGF were inversely associated with progression-free survival (PFS) and OS [49, 76, 94, 124, 188]. Elevated levels of these CP markers may reflect more aggressive tumors with extensive angiogenesis and subsequent leakage of tumor-derived molecules into the circulation. Furthermore, a stress response of the body, represented by elevated levels of C-reactive protein (CRP), the S100B protein, D-dimer and several heat shock proteins, has been associated with worse prognosis $[65,110,158,175]$. Altogether, the most promising prognostic $\mathrm{CP}$ marker for glioma patients thus far seems to be serum YKL-40 protein.

\section{Predictive circulating protein markers}

Predictive CP markers in patients with glioma may facilitate therapy selection without the need for invasive tumor tissue biopsies. So far, predictive CP markers for patients with diffuse glioma were mainly identified in phase I and II clinical trials testing the effect of anti-angiogenic treatments (esp. bevacizumab). Nevertheless, also for other established therapy regimens in patients with glioma, like TMZ treatment (see also CNAs), predictive CP markers might contribute to patient stratification. Tabouret et al. [165] reported that increased plasma protein levels of MMP-2 (>227.5 ng/ml) prior to combinatorial bevacizumab and irinotecan treatment were associated with higher probability of response to treatment $(83 \%$ compared to $15 \%$ ). Decreased plasma protein levels of MMP-9 $(<235 \mathrm{ng} / \mathrm{ml})$ were considered to be related to treatment response, although this was not confirmed in an additional patient cohort [165]. In a relatively small study $(n=10$ recurrent glioblastoma patients), Chinnaiyan et al. [34] identified IGFBP-5 as a possible predictive protein marker for combined treatment with bevacizumab, HDAC inhibitor vorinostat, and irinotecan. Finally, non-responders to a combination therapy with bevacizumab and irinotecan had significantly increased plasma levels of IL-8 and G-CSF prior to start of the treatment as compared to responders [46].

Monitoring circulating protein markers

Circulating protein markers in patients with glioma that can be potentially employed to monitor the efficacy of a particular treatment are gaining attention. The individual biological tumor properties and complex tissue alterations induced by different anti-tumor treatments are not properly assessed with current MR imaging protocols and response criteria [181]. These criteria consider in particular two of the imaging characteristics: contrast uptake and alteration of the T2-weighted signal. Both characteristics, however, do not always properly reflect tumor behavior. Contrast enhancement indicates disruption of the blood-brain barrier related to tumor progression, but anti-angiogenic treatment reduces the number and permeability of tumor blood vessels and decreases the amount of MR contrast agent in the tumor, resulting in potential misinterpretation of tumor 
regression (pseudo-response), whereas combined chemoirradiation may lead to temporarily increased contrast enhancement, erroneously interpreted as tumor progression (pseudo-progression). T2-weighted signal changes suggest diffuse infiltrative tumor progression, but might also be caused by tumor- or treatment-induced edema, resulting in misinterpretation as progression [163].

Blood-based biomarkers may allow circumvention of problematic pseudo-responses upon anti-angiogenesis treatment and pseudo-progression upon chemoradiotherapy treatment. Two studies that together included approximately 90 recurrent glioblastoma patients treated with bevacizumab plus irinotecan demonstrated that a decreased plasma protein level of VEGF, measured, respectively, eight weeks and 15 days after the start of the treatment, was associated with improved PFS and OS [46, 165]. In addition, decreased plasma protein levels of MMP-9 were associated with prolonged PFS and OS, whereas changes in the plasma protein levels of bFGF, SDF-1a, PIGF or VEGFR-2 were not associated with the effect of bevacizumab [165]. Unfortunately, baseline levels of VEGF was not associated with PFS in the larger AVAglio study $(n=571)$ [139]. Treatment responses of recurrent glioblastoma patients $(n=26)$ treated with the VEGF and PIGF sequestering drug aflibercept were not associated with significant changes in plasma protein levels of VEGF, despite initial reduction of this marker in plasma and subsequent increases of circulating VEGF and PIGF after 2 weeks of treatment [62]. Nevertheless, increased expression of MMP-9 and certain chemokines (e.g., MCTP3, MIF, IP-10) was correlated with tumor progression after 28 days of treatment, and may serve as putative CP monitoring markers for aflibercept treatment.

Multiple studies assessing the efficacy of the panVEGFR RTK inhibitor cediranib in both newly diagnosed and recurrent glioblastoma patients have included circulating biomarker discovery as an important component of the clinical trials. CPs were assessed in plasma and urine samples at different time points during treatment. Most notably, in recurrent glioblastoma patients, increased plasma protein levels of PIGF and IL-8 and decreased levels of bFGF and sTie-2 proteins were associated with partial radiological responses, whereas increased plasma protein levels of sVEGFR-1, sTie-2 and SDF-1a and decreased levels of PIGF correlated with radiological progression. Furthermore, a trend was observed between bFGF and SDF-1a levels, tumor vessel size and tumor progression. Increased plasma levels of PIGF and bFGF measured one day after start of treatment for recurrent glioblastoma correlated with improved OS. Increased plasma levels of MMP-2 and urine levels of MMP-9 measured within 1 day after the start of treatment were associated with shorter OS and PFS, respectively $[11,13]$. In a trial assessing the efficacy of cediranib combined with standard treatment in newly diagnosed glioblastoma patients, increased plasma protein levels of sVEGFR-1 and IL-8, after, respectively, 29 and 48 days of treatment, were associated with reduced PFS [12]. MMP-9 and sVEGFR-1 were identified in plasma as potential CP monitoring markers for a combination therapy of TMZ plus the VEGF and PDGFR inhibitor vatalanib [56].

\section{Circulating nucleic acids (CNA)}

Tumor-associated CNAs have been identified in the blood of patients with several types of cancer as early as 1977 [50, 93], and may be suitable for diagnosis and monitoring of tumor treatment $[44,114]$. Several classes of CNAs are detected; ctDNA including methylated DNA, mRNA, and small RNAs including miRNAs and transfer RNAs (tRNAs) (Fig. 1). Tumor-derived nucleic acids can be detected as cell-free entities, attached to lipid or protein structures, or as content of circulating EVs or blood platelets $[38,40,43,116,150,155]$. Of note, in a large study in which the presence of detectable ctDNA in several types of cancer was assessed only in a minority (10\%) of patients with glioma ctDNA was detected [16], indicating that the use of this biomarker in this patient category is challenging. In this section, we summarize the literature on CNAs in patients with diffuse glioma, while Supplementary Table 2 provides a comprehensive overview of relevant studies on this topic.

\section{Diagnostic circulating nucleic acid biomarkers}

So far, most diagnostic CNA markers in patients with glioma were detected by miRNA profiling. Circulating miRNAs exhibit great stability in plasma and serum $[33,111]$, and their involvement in glioma pathogenesis has been extensively studied [112]. Several groups reported that differential expression of multiple miRNA sets in plasma, serum and blood cells distinguishes glioma patients from healthy controls [74, 103, 136, 152, 178, 190]. Unfortunately, the overlap between studies regarding plasma miRNA biomarkers is limited, and further validation is needed. Two studies compared the content of small RNAs in serum-derived EVs from patients with glioblastoma and healthy controls. Interestingly, RNA isolated from EVs appeared to be enriched for small RNAs in both healthy individuals and glioblastoma patients [117]. Based on the small RNA content, patients with glioblastoma could be distinguished from healthy controls [106]. Of note, it was recently reported that miRNAs are post-transcriptionally modified by the enzymatic addition of nucleotides at the $3^{\prime}$-end of the mature miRNA, thereby affecting their release by tumor cells [86]. Hence, for miRNA biomarker 
studies in liquid biopsies it is of crucial importance to take into account the presence of such non-templated nucleotide additions, possibly changing the CNA biomarker landscape. Other serum CNA markers such as loss of heterozygosity (LOH) of chromosome arms 1p, 19q and 10q, and methylation of $p 16 / I N K 4 a$ and RASSF $1 A$ were also associated with the ability to identify patients with particular types of brain tumors [92, 105, 176]. Additionally, measurements of methylation of circulating ALU repeat sequences (i.e., non-coding transposable elements integrated in the human genome) in plasma demonstrated a significant correlation with tissue methylation and were reported to allow for distinguishing low- from high-grade glioma patients and healthy controls [31].

Prognostic circulating nucleic acid biomarkers

The number of prognostic CNA biomarkers identified in patients with diffuse glioma so far is limited. Liu et al. [96] identified an association between hypermethylation of both MGMT and thrombospondin-1 in plasma of grade II and grade IV glioma patients and, counter-intuitively, an inferior OS. However, the authors do not provide detailed information on treatment regimens that may well have had an impact on the outcome of the included patients. In contrast, in a prospective study collecting longitudinal plasma samples from grade II-IV glioma patients, presence of methylated MGMT was associated with increased PFS and OS [48]. Finally, both increased plasma levels of miR454-3p and hypomethylation of ALU repeat elements in serum were reported to be associated with worse prognosis $[31,152]$.

Predictive circulating nucleic acid biomarkers

Predictive properties of CNA biomarkers were predominantly studied for MGMT promoter methylation, EGFRvIII and the IDHI RI32H mutation. In this respect, EGFRvIII and $I D H 1 R 132 H$ are regarded as companion diagnostic biomarkers. Patients with methylated MGMT detected in serum ctDNA showed a significantly higher response to $\mathrm{BCNU}$ treatment, measured by imaging and clinical examination, compared to non-methylated MGMT ctDNA [8]. However, methylated $M G M T$ in serum did not predict treatment response to the combination therapy of TMZ and cisplatin, possibly due to the inhibitory effect of cisplatin on the MGMT enzyme [8, 21, 177]. Of note, these authors demonstrated a sensitivity of $\sim 50-80 \%$ and a specificity of $100 \%$ of methylated MGMT in serum and plasma compared to the result of MGMT analysis of the tumor tissue (Supplementary Table 3). Detection of specific mutations and deletion variants is of interest for integration of blood-based markers in clinical trials, e.g., for the EGFRvIII-targeted immunotherapy using rindopepimut (CDX-110). Rindopepimut is currently being evaluated in a phase III study for newly diagnosed glioblastoma patients (ACT IV) and in a phase II study for recurrent glioblastoma patients in combination with GM-CSF (ReACT) [6]. Recently, EGFRvIII RNA has been detected in serum EVs of glioma patients [155] and EGFRvIII ctDNA in plasma [140]. Moreover, Nilsson et al. [116] documented efficient uptake of EVs by blood platelets and detected EGFRvIII mRNA in these elements. Based on this information, diagnosis of EGFRvIII through liquid biopsies could allow for patient selection for specific anti-EGFRvIII treatment during clinical follow-up and possibly also for treatment monitoring. In addition, blood-based diagnosis of EGFRvIII may help to circumvent the possible underdiagnosis of heterogeneously expressed EGFRvIII in tumor tissue. Another genetic event of particular interest for use in companion diagnostics is the IDHI RI32H mutation [121, 135]. Although the IDHI mutation was detected in CSF EVs of glioblastoma patients, it could not be detected in serum EVs of the same patients [30, 32]. Boissellier et al. [19] detected mutant IDHI ctDNA with a sensitivity of $60 \%$ and a specificity of $100 \%$. In this study, detection of mutant IDHI in LGG patients depended on tumor volume and in high-grade glioma patients on the presence of contrast enhancement as visualized by MR imaging.

\section{Monitoring circulating nucleic acid biomarkers}

EGFRvIII ctDNA, or EGFRvIII mRNA in EVs or platelets may be considered as a monitoring marker in studies of therapeutics specifically or indirectly targeting EGFRvIII. The loss of ctDNA EGFRvIII was noted in two patients following gross total resection of the tumor [140]. Furthermore, assessment of the MGMT methylation status in blood during TMZ treatment revealed that the cumulative incidence of unmethylated $M G M T$ promoter, measured in longitudinal samples from 58 patients with diffuse glioma, increased from $58 \%$ at the start of TMZ treatment to $92 \%$ after 12 months of follow-up. This may be explained by the selection and outgrowth of tumor subclones with unmethylated MGMT promoter during TMZ treatment [48]. Circulating miRNA markers, which raised to reference levels of healthy controls following surgery and radio-chemotherapy of patients with diffuse glioma, may also have monitoring value [178, 190]. Furthermore, the significantly higher levels of miR-23, $-150,-197$ and $-548 b-5 p$ were reported to occur in serum of patients with radiation necrosis/astrogliosis $(n=11)$ rather than in patients with diffuse glioma and may be of value to distinguish tumor progression from pseudo-progression after radiation (AUC: $0.9595 \% \mathrm{CI}$ 0.902-0.998) [190]. 


\section{Circulating tumor cells (CTCs)}

Circulating tumor cells are neoplastic cells that are detected in the circulation, and that can potentially be used as biomarker biosource [120]. CTCs are isolated through sophisticated techniques that separate CTCs from other blood cells by their unique physical and biological properties [3]. While previous attempts to isolate glioma CTCs were unsuccessful $[18,107]$, three independent research groups recently reported isolation of CTCs from glioma patients using three different novel isolation and detection methods (see also Supplemental Table 2). First, fluorescence immunocytochemistry was performed on purified mononuclear cells for GFAP-positive, CD45-negative CTCs. In 28 out of 141 glioblastoma patients, CTCs were identified, while these CTCs were not detected in patients with brain metastases. Following surgery, no significant difference was observed in CTC counts before, during or after surgery and no correlation between CTC counts and clinical outcome was found [113]. Second, a telomerase-responsive adenoviral vector encoding a fluorescent reporter was employed to detect hTERT-positive cells, resulting in detection of CTCs in 8 out of 11 glioblastoma patients analyzed before radiotherapy and TMZ treatment. In two patients, the quantitation of CTCs allowed the separation of pseudoprogression from tumor progression as measured by MR imaging [104]. Finally, Sullivan et al. applied a CTC-iChip, which allows the removal of anucleated cells and depletion of leukocytes from the remaining cell pellet via magnetically tagged antibodies (CD16, CD45), yielding untagged and un-manipulated CTCs. Next, fluorescent probes targeting five markers for glioma cells (termed STEAM: Sox2, Tubulin beta-3, EGFR, A2B5, c-Met) were introduced. In 13 out of 33 glioblastoma patients, CTCs were detected. CTCs were enriched for transcripts associated with a mesenchymal glioblastoma signature. Interestingly, the expression levels of these transcripts were not always in accordance with the signature that was detected in the tissue of the corresponding glial tumor, suggesting a preference of a particular subset of tumor cells (not necessarily being the predominant tumor cell population) for entering the circulation. Moreover, no additional correlations between CTCs and clinical parameters were observed [162]. Of note, a potential role for circulating endothelial (precursor) cells and T-lymphocytes (esp. T-regulatory cells) as diagnostic, prognostic, predictive, and monitoring markers in patients with diffuse glioma has been suggested [5, 13, 37, 42, 47, 60, 61, 128, 130, 184, 193]. In addition, immune cells release a broad range of CPs that could be of interest in this respect. The diagnostic value of immune cell-derived CNAs remains to be investigated [187]. In conclusion, successful isolation of CTCs from the blood of glioma patients was demonstrated using different techniques. In 20-73\% of high-grade glioma patients CTCs were detected. It remains to be evaluated whether glioma CTCs fully represent the heterogeneous tumor cell population, and what the diagnostic, prognostic, predictive and monitoring potential of CTCs is in patients with diffuse gliomas.

\section{Conclusions and future directions}

Biomarkers can be isolated from biofluids such as blood, and also CSF and urine. There is a plethora of small and mainly explorative studies describing blood-based biomarkers in patients with diffuse glioma. The use of different techniques and methodologies for detection of the biomarkers and the mainly retrospective nature of the studies complicates drawing solid conclusions. In Fig. 2, we provide an overview of the biomarkers in liquid biopsies reported to be of potential relevance for diagnosis and/or management of patients with diffuse glioma. All blood-based biomarkers reported until now need further validation. Meanwhile, in the near future assessment of blood-based biomarkers can be expected to improve patient stratification and monitoring. Ideally, phase I trials should already include biomarker discovery, with further validation of potential biomarkers in phase II and III trials, including determination of proper cutoff values for biomarkers [77]. Furthermore, additional studies are needed that uncover potential circulating biomarkers accompanying MR imaging during clinical followup for, e.g., LGG patients. Finally, markers suggested in this review such as PIGF and GFAP have to be evaluated for its diagnostic potential for difficult-to-diagnose patients (e.g., in the differential diagnosis of metastasis versus primary brain tumor). The evaluation of biomarker panels $[39,45,151]$, instead of sole biomarkers, using standardized detection methods, could be useful for further enhancing the sensitivity and specificity of blood tests [167]. This could be accompanied by a two or more steps decision tree algorithm as was recently shown for three diagnostic CP markers (GFAP, IGFBP-2, and YKL-40) [52]. The use of "omic-approaches" is likely to boost such a biomarker panel analysis [20, 55, 82, 83, 89, 97, 115, 148, 194].

The most extensively studied CP biomarkers are circulating angiogenesis-related proteins. While such proteins may indeed be useful as prognostic and monitoring biomarkers for anti-angiogenic therapies, a robust biomarker for the monitoring of bevacizumab treatment (i.e., the most widely applied anti-angiogenic therapy to date) has not yet been reported. Additionally, the discovery of tumor-derived ctDNA, circulating miRNAs, EVs and platelets sequestering tumor-derived EGFRvIII do point at the possibility to use blood as a source of CNA biomarkers in patients with diffuse glioma. An advantage of CNA biomarkers is the possibility to detect genetic aberrations such as $I D H I$ 


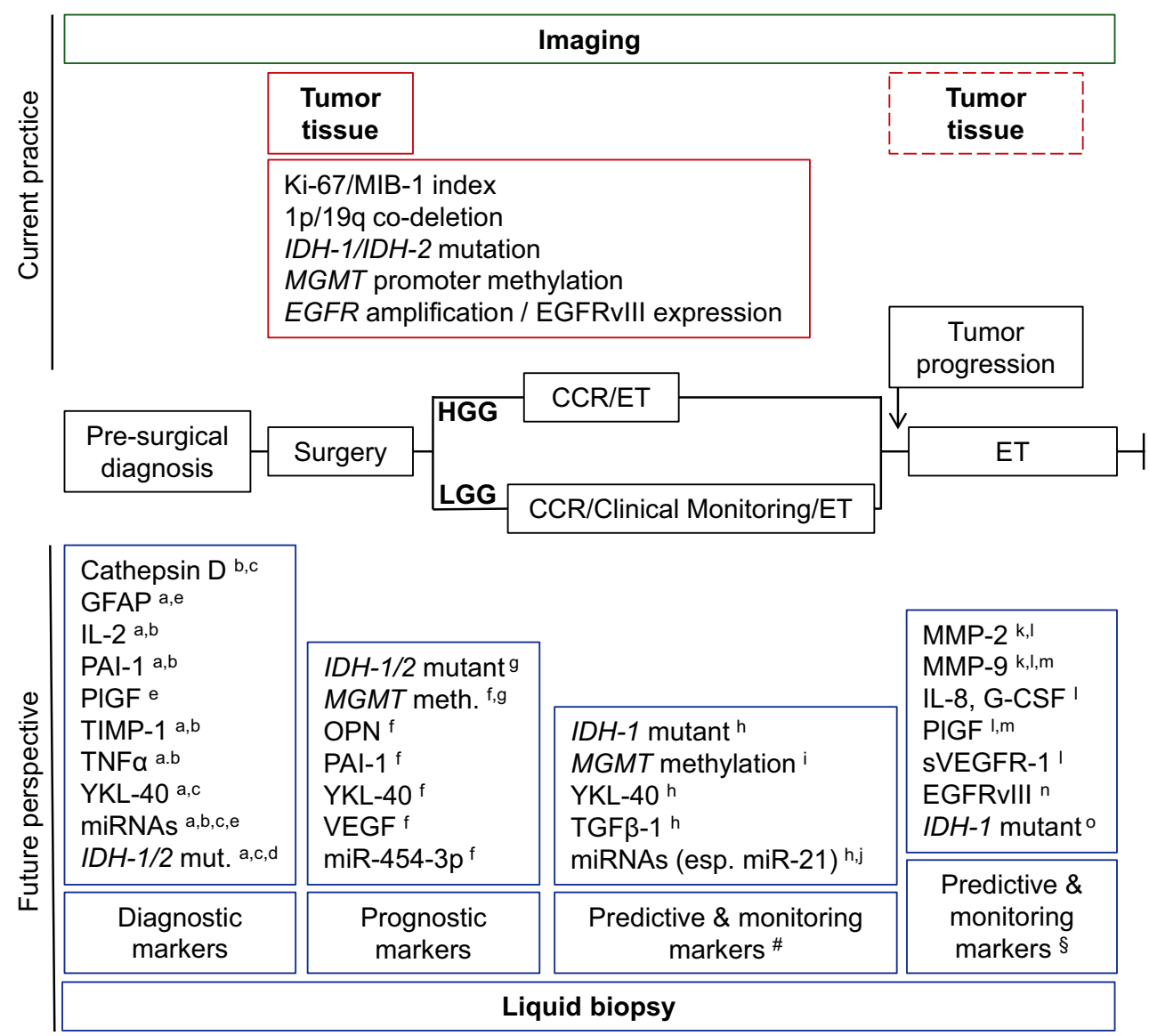

Fig. 2 Example of molecular biomarker assessment using liquid biopsy in patients with low- and high-grade glioma. Central black line depicts a simplified timeline of clinical events for patients with low- or high-grade glioma (LGG versus HGG). A pre-surgical working diagnosis (based on esp. clinical and radiological investigations) leads to surgery (biopsy or resection of tumor tissue). After a pathological diagnosis is made, most glioma patients receive 'conventional chemo- and/or radiotherapy' (CCR), but in LGG patients clinical monitoring is also (still) common practice. Especially after failure of CCR, experimental therapy (ET) can be administered. Above the timeline, imaging (available during the entire follow-up of the patient) and the most widely accepted molecular biomarkers analyzed in diffuse glioma tissue samples are depicted. Tumor tissue samples are obtained during surgery, and might again be obtained at the moment of tumor progression (dashed line box). The boxes below the timeline show promising blood-based biomarkers as deduced from this review and grouped according to their potential meaning

mutations and EGFRvIII, which are of special interest as predictive markers for current clinical trials. Acknowledging that ctDNA so far was measurable in only a minority of patients with a diffuse glioma, detection of RNA might be more sensitive as compared to ctDNA, especially when analyzing the fraction of EVs or blood platelet in which RNAs are protected from circulating nucleases [16]. Assessment of circulating biomarkers may be of particular value for molecular markers that are known to be heterogeneously distributed (with a danger of sampling error) such (diagnostic, prognostic, predictive, monitoring) in different phases of the disease process. The blood-based biomarkers mentioned here are selected based on the number of studies measuring the biomarker and the number of patients included in these studies. Each character indicates for which group of diffuse glioma patients or treatment the biomarker might be suitable. "Predictive and monitoring markers selected for CCR regimens (temozolomide and procarbazine-lomustine-vincristine treatment). ${ }^{\S}$ Predictive and monitoring markers selected for experimental therapies (see also individual characters). Characters accompanying biomarkers: $a$ primary GBM (pGBM) vs. healthy controls, $b$ pGBM vs. LGG, $c$ LGG vs. healthy control, $d$ secondary GBM vs pGBM, $e$ primary diffuse glioma vs. metastasis to the brain, $f$ HGG, $g$ LGG, $h$ surgery, $i$ temozolomide treatment, $j$ chemoradiotherapy, $k$ bevacizumab and irinotecan treatment, $l$ cediranib treatment, $m$ aflibercept treatment, $n$ rindopepimut (antiEGFRvIII) treatment, $o$ IDHI mutant inhibitor AGI-5198

as EGFRvIII. Also, IDHI mutations detected in ctDNA and EVs isolated from CSF may provide a way for non-invasive assessment of diagnostic and prognostic properties.

Thus far, many different tumor-related and tumorderived markers have been identified in the circulation of patients with glioma that might attribute as specific biomarkers. Rational selection of the most promising biomarkers for incorporation in clinical trials is warranted, with literature mining as an important tool for such a selection. Potential biomarkers extracted from the present review of 
the literature for different stages of clinical management of patients with diffuse gliomas are summarized in Fig. 2. Obviously, regular and systematic evaluation of promising blood-based biomarkers, preferable on an international level via research communities such as the EORTC, would improve the assessment of their clinical value. Systematic collection of blood samples for future biomarker discovery and the establishment of blood biobanks, also outside clinical trails, would be very helpful in this respect. Ideally, such samples would be collected both prior to treatment (to allow for identification of diagnostic, prognostic and predictive biomarkers) as well as during therapy, the latter in particular situations in which robust predictive and monitoring biomarkers are still lacking (e.g., bevacizumab treatment).

Blood-based liquid biopsies are of interest for the longitudinal monitoring of tumor activity and therapy response. Depending on the blood fraction (i.e., serum or plasma), levels of CPs, CNAs, and possibly CTCs may vary considerably. Some markers have demonstrated biomarker value in plasma, whereas others were only of potential value in serum [188]. Also, used assays and methodologies for detection of CPs, (modified) CNAs and CTCs, each with its own strengths and weaknesses, have to be critically considered, and standardization is required to be able to compare results between studies. Furthermore, storage conditions of liquid biopsy samples require consideration, as well as other variables such as disease state, histological tumor subtype, time of sampling, biosource and biomarker isolation procedures, treatment regimen, assay reproducibility and sensitivity, protein half-life, biological processes, and normalization standards $[25,29,39,58,73,78,79$, $138,147,153,173,186,195]$. Of note, the sequestration of several proteins and nucleic acids in platelets and the potential release of proteins and nucleic acids by platelets and immune cells during surgery and blood processing have to be taken into account $[39,85,147]$. Therefore, to thoroughly address these issues and to control for them, large standardized clinical studies, requiring specific study designs and well-validated molecular assays, will be of critical importance. Importantly, proper selection of a control group with a disease that is a meaningful differential diagnosis for glioma patients (e.g., tumor metastasis to the brain, primary CNS lymphoma, or infection) is important, especially in biomarker discovery $[52,126]$. Conventional biomarker discovery using state-of-the-art next-generation DNA/RNA sequencing or protein quantifications can be expected to yield novel biomarkers correlated to a specific disease state.

In conclusion, the interest in liquid biopsies for the diagnostics of glioma is rapidly expanding. In recent years, many circulating biomarkers have been detected, evaluated and integrated in clinical trials. In the coming years, more large-scale biomarker discovery efforts in patients with diffuse gliomas can be expected. Advances in the development of more sensitive assays allow for detection of low abundant (mutant) biomolecules in the circulation, further expanding the width of assessable biomarkers. Selection and validation of potential circulating biomarkers for patients with diffuse glioma is warranted. In the future, blood-based companion diagnostics may improve the drug discovery process for diffuse glioma patients and further individualize the therapy of these patients. Within the coming decade, the ongoing research may well result in an interdisciplinary transformation of the classical blood-based analyses towards the routine use of liquid biopsies for molecular diagnostics, similarly as we observed for tissue biopsies.

Acknowledgments Financial support was provided by European Research Council 336540, the Netherlands Organisation of Scientific Research 91711366, the Dutch Cancer Society (grant project VU 2013-5751), and STOPhersentumoren.nl.

Open Access This article is distributed under the terms of the Creative Commons Attribution License which permits any use, distribution, and reproduction in any medium, provided the original author(s) and the source are credited.

\section{References}

1. Akers JC, Ramakrishnan V, Kim R, Skog J, Nakano I, Pingle S, Kalinina J, Hua W, Kesari S, Mao Y, Breakefield XO, Hochberg FH, Van Meir EG, Carter BS, Chen CC (2013) MiR-21 in the extracellular vesicles (EVs) of cerebrospinal fluid (CSF): a platform for glioblastoma biomarker development. PLoS One 8:e78115. doi:10.1371/journal.pone.0078115

2. Albulescu R, Codrici E, Popescu ID, Mihai S, Necula LG, Petrescu D, Teodoru M, Tanase CP (2013) Cytokine patterns in brain tumour progression. Mediators Inflamm 2013:979748. doi:10.1155/2013/979748

3. Alix-Panabières C, Pantel K (2013) Circulating tumor cells: liquid biopsy of cancer. Clin Chem 59:110-118. doi:10.1373/ clinchem.2012.194258

4. Al-Nedawi K, Meehan B, Micallef J, Lhotak V, May L, Guha A, Rak J (2008) Intercellular transfer of the oncogenic receptor EGFRvIII by microvesicles derived from tumour cells. Nat Cell Biol 10:619-624. doi:10.1038/ncb1725

5. El Andaloussi A, Lesniak MS (2006) An increase in CD4+ CD25+ FOXP3 + regulatory $\mathrm{T}$ cells in tumor-infiltrating lymphocytes of human glioblastoma multiforme. Neuro Oncol 8:234-243. doi:10.1215/15228517-2006-006

6. Babu R, Adamson DC (2012) Rindopepimut: an evidence-based review of its therapeutic potential in the treatment of EGFRvIIII-positive glioblastoma. Core Evid 7:93-103. doi:10.2147/CE.S29001

7. Bailey P (1926) A classification of the tumors of the glioma group on a histogenetic basis with a correlated study of prognosis. Lippincott, Philadelphia

8. Balaña C, Ramirez JL, Taron M, Roussos Y, Ariza A, Ballester R, Sarries C, Mendez P, Sanchez JJ, Rosell R (2003) O6-methyl-guanine-DNA methyltransferase methylation in serum and tumor DNA predicts response to 1,3-bis(2chloroethyl)-1-nitrosourea but not to temozolamide plus cisplatin in glioblastoma multiforme. Clin Cancer Res 9:1461-1468 
9. Baldock AL, Yagle K, Born DE, Ahn S, Trister AD, Neal M, Johnston SK, Bridge CA, Basanta D, Scott J, Malone H, Sonabend AM, Canoll P, Mrugala MM, Rockhill JK, Rockne RC, Swanson KR (2014) Invasion and proliferation kinetics in enhancing gliomas predict IDH1 mutation status. Neuro Oncol 16:779-786. doi:10.1093/neuonc/nou027

10. Baraniskin A, Kuhnhenn J, Schlegel U, Maghnouj A, Zöllner H, Schmiegel W, Hahn S, Schroers R (2012) Identification of microRNAs in the cerebrospinal fluid as biomarker for the diagnosis of glioma. Neuro Oncol 14:29-33. doi:10.1093/neuonc/ nor169

11. Batchelor TT, Duda DG, di Tomaso E, Ancukiewicz M, Plotkin SR, Gerstner E, Eichler AF, Drappatz J, Hochberg FH, Benner T, Louis DN, Cohen KS, Chea H, Exarhopoulos A, Loeffler JS, Moses MA, Ivy P, Sorensen AG, Wen PY et al (2010) Phase II study of cediranib, an oral pan-vascular endothelial growth factor receptor tyrosine kinase inhibitor, in patients with recurrent glioblastoma. J Clin Oncol 28:2817-2823. doi:10.1200/ JCO.2009.26.3988

12. Batchelor TT, Gerstner ER, Emblem KE, Duda DG, KalpathyCramer J, Snuderl M, Ancukiewicz M, Polaskova P, Pinho MC, Jennings D, Plotkin SR, Chi AS, Eichler AF, Dietrich J, Hochberg FH, Lu-Emerson C, Iafrate AJ, Ivy SP, Rosen BR et al (2013) Improved tumor oxygenation and survival in glioblastoma patients who show increased blood perfusion after cediranib and chemoradiation. Proc Natl Acad Sci 110:1905919064. doi:10.1073/pnas.1318022110

13. Batchelor TT, Sorensen AG, di Tomaso E, Zhang W-T, Duda DG, Cohen KS, Kozak KR, Cahill DP, Chen P-J, Zhu M, Ancukiewicz M, Mrugala MM, Plotkin S, Drappatz J, Louis DN, Ivy P, Scadden DT, Benner T, Loeffler JS et al (2007) AZD2171, a pan-VEGF receptor tyrosine kinase inhibitor, normalizes tumor vasculature and alleviates edema in glioblastoma patients. Cancer Cell 11:83-95. doi:10.1016/j.ccr.2006.11.021

14. Beiko J, Suki D, Hess KR, Fox BD, Cheung V, Cabral M, Shonka N, Gilbert MR, Sawaya R, Prabhu SS, Weinberg J, Lang FF, Aldape KD, Sulman EP, Rao G, McCutcheon IE, Cahill DP (2014) IDH1 mutant malignant astrocytomas are more amenable to surgical resection and have a survival benefit associated with maximal surgical resection. Neuro Oncol 16:81-91. doi:10.1093/neuonc/not159

15. Bernardi D, Padoan A, Ballin A, Sartori M, Manara R, Scienza R, Plebani M, Della Puppa A (2012) Serum YKL-40 following resection for cerebral glioblastoma. J Neurooncol 107:299-305. doi:10.1007/s11060-011-0762-7

16. Bettegowda C, Sausen M, Leary RJ, Kinde I, Wang Y, Agrawal $\mathrm{N}$, Bartlett BR, Wang H, Luber B, Alani RM, Antonarakis ES, Azad NS, Bardelli A, Brem H, Cameron JL, Lee CC, Fecher LA, Gallia GL, Gibbs P et al (2014) Detection of circulating tumor DNA in early- and late-stage human malignancies. Sci Transl Med 6:224ra24. doi:10.1126/scitranslmed.3007094

17. Blennow K, Hampel H, Weiner M, Zetterberg H (2010) Cerebrospinal fluid and plasma biomarkers in Alzheimer disease. Nat Rev Neurol 6:131-144. doi:10.1038/nrneurol.2010.4

18. Böhm C, Wassmann H, Paulus W (2003) No evidence of tumour cells in blood of patients with glioma. Mol Pathol 56:187-189

19. Boisselier B, Gállego Pérez-Larraya J, Rossetto M, Labussière M, Ciccarino P, Marie Y, Delattre J-Y, Sanson M (2012) Detection of IDH1 mutation in the plasma of patients with glioma. Neurology 79:1693-1698. doi:10.1212/WNL.0b013e31826e9b0a

20. De Bont JM, den Boer ML, Reddingius RE, Jansen J, Passier M, van Schaik RHN, Kros JM, Sillevis Smitt PA, Luider TH, Pieters R (2006) Identification of apolipoprotein A-II in cerebrospinal fluid of pediatric brain tumor patients by protein expression profiling. Clin Chem 52:1501-1509. doi:10.1373/ clinchem.2006.069294
21. Brandes AA, Basso U, Reni M, Vastola F, Tosoni A, Cavallo G, Scopece L, Ferreri AJ, Panucci MG, Monfardini S, Ermani M (2004) First-line chemotherapy with cisplatin plus fractionated temozolomide in recurrent glioblastoma multiforme: a phase II study of the Gruppo Italiano Cooperativo di Neuro-Oncologia. J Clin Oncol 22:1598-1604. doi:10.1200/JCO.2004.11.019

22. Brennan CW, Verhaak RGW, McKenna A, Campos B, Noushmehr H, Salama SR, Zheng S, Chakravarty D, Sanborn JZ, Berman SH, Beroukhim R, Bernard B, Wu C-J, Genovese G, Shmulevich I, Barnholtz-Sloan J, Zou L, Vegesna R, Shukla SA et al (2013) The somatic genomic landscape of glioblastoma. Cell 155:462-477. doi:10.1016/j.cell.2013.09.034

23. Brinker T, Stopa E, Morrison J, Klinge P (2014) A new look at cerebrospinal fluid circulation. Fluids Barriers CNS 11:10. doi:10.1186/2045-8118-11-10

24. Brommeland T, Rosengren L, Fridlund S, Hennig R, Isaksen V (2007) Serum levels of glial fibrillary acidic protein correlate to tumour volume of high-grade gliomas. Acta Neurol Scand 116:380-384. doi:10.1111/j.1600-0404.2007.00889.x

25. Bush MA, Samara E, Whitehouse MJ, Yoshizawa C, Novicki DL, Pike M, Laham RJ, Simons M, Chronos NA (2001) Pharmacokinetics and pharmacodynamics of recombinant FGF-2 in a phase I trial in coronary artery disease. J Clin Pharmacol 41:378-385

26. Campos S, Davey P, Hird A, Pressnail B, Bilbao J, Aviv RI, Symons S, Pirouzmand F, Sinclair E, Culleton S, Desa E, Goh P, Chow E (2009) Brain metastasis from an unknown primary, or primary brain tumour? A diagnostic dilemma. Curr Oncol 16:62-66

27. Capper D, Simon M, Langhans C-D, Okun JG, Tonn JC, Weller M, von Deimling A, Hartmann C (2012) 2-Hydroxyglutarate concentration in serum from patients with gliomas does not correlate with IDH1/2 mutation status or tumor size. Int J Cancer 131:766-768. doi:10.1002/ijc.26425

28. Carlsson A, Persson O, Ingvarsson J, Widegren B, Salford L, Borrebaeck CAK, Wingren C (2010) Plasma proteome profiling reveals biomarker patterns associated with prognosis and therapy selection in glioblastoma multiforme patients. Proteomics Clin Appl 4:591-602. doi:10.1002/prca.200900173

29. Carson KA, Grossman SA, Fisher JD, Shaw EG (2007) Prognostic factors for survival in adult patients with recurrent glioma enrolled onto the new approaches to brain tumor therapy CNS consortium phase I and II clinical trials. J Clin Oncol 25:2601-2606. doi:10.1200/JCO.2006.08.1661

30. Chen C, Skog J, Hsu C-H, Lessard RT, Balaj L, Wurdinger T, Carter BS, Breakefield XO, Toner M, Irimia D (2010) Microfluidic isolation and transcriptome analysis of serum microvesicles. Lab Chip 10:505-511. doi:10.1039/b916199f

31. Chen J, Gong M, Lu S, Liu F, Xia L, Nie D, Zou F, Shi J, Ju S, Zhao L, Zuo H, Qi J, Shi W (2013) Detection of serum Alu element hypomethylation for the diagnosis and prognosis of glioma. J Mol Neurosci 50:368-375. doi:10.1007/ s12031-013-0014-8

32. Chen WW, Balaj L, Liau LM, Samuels ML, Kotsopoulos SK, Maguire CA, Loguidice L, Soto H, Garrett M, Zhu LD, Sivaraman S, Chen C, Wong ET, Carter BS, Hochberg FH, Breakefield XO, Skog J (2013) BEAMing and droplet digital PCR analysis of mutant IDH1 mRNA in glioma patient serum and cerebrospinal fluid extracellular vesicles. Mol Ther Nucleic Acids 2:e109. doi:10.1038/mtna.2013.28

33. Chen X, Ba Y, Ma L, Cai X, Yin Y, Wang K, Guo J, Zhang Y, Chen J, Guo X, Li Q, Li X, Wang W, Zhang Y, Wang J, Jiang X, Xiang Y, Xu C, Zheng P et al (2008) Characterization of microRNAs in serum: a novel class of biomarkers for diagnosis of cancer and other diseases. Cell Res 18:997-1006. doi:10.1038/ cr.2008.282 
34. Chinnaiyan P, Chowdhary S, Potthast L, Prabhu A, Tsai Y-Y, Sarcar B, Kahali S, Brem S, Yu HM, Rojiani A, Murtagh R, Pan E (2012) Phase I trial of vorinostat combined with bevacizumab and CPT-11 in recurrent glioblastoma. Neuro Oncol 14:93-100. doi:10.1093/neuonc/nor187

35. Chinot OL, Wick W, Mason W, Henriksson R, Saran F, Nishikawa R, Carpentier AF, Hoang-Xuan K, Kavan P, Cernea D, Brandes AA, Hilton M, Abrey L, Cloughesy T (2014) Bevacizumab plus radiotherapy-temozolomide for newly diagnosed glioblastoma. N Engl J Med 370:709-722. doi:10.1056/ NEJMoa1308345

36. Claes A, Idema AJ, Wesseling P (2007) Diffuse glioma growth: a guerilla war. Acta Neuropathol 114:443-458. doi:10.1007/ s00401-007-0293-7

37. Corsini E, Ciusani E, Gaviani P, Silvani A, Canazza A, Bernardi G, Calatozzolo C, DiMeco F, Di Meco F, Salmaggi A (2012) Decrease in circulating endothelial progenitor cells in treated glioma patients. J Neurooncol 108:123-129. doi:10.1007/ s11060-012-0805-8

38. Cortez MA, Bueso-Ramos C, Ferdin J, Lopez-Berestein G, Sood AK, Calin GA (2011) MicroRNAs in body fluids-the mix of hormones and biomarkers. Nat Rev Clin Oncol 8:467-477. doi:10.1038/nrclinonc. 2011.76

39. Crocker M, Ashley S, Giddings I, Petrik V, Hardcastle A, Aherne W, Pearson A, Bell BA, Zacharoulis S, Papadopoulos MC (2011) Serum angiogenic profile of patients with glioblastoma identifies distinct tumor subtypes and shows that TIMP-1 is a prognostic factor. Neuro Oncol 13:99-108. doi:10.1093/ neuonc/noq170

40. Crowley E, Di Nicolantonio F, Loupakis F, Bardelli A (2013) Liquid biopsy: monitoring cancer-genetics in the blood. Nat Rev Clin Oncol 10:472-484. doi:10.1038/nrclinonc.2013.110

41. Cuddapah VA, Robel S, Watkins S, Sontheimer H (2014) A neurocentric perspective on glioma invasion. Nat Rev Neurosci 15:455-465. doi:10.1038/nrn3765

42. Cuppini L, Calleri A, Bruzzone MG, Prodi E, Anghileri E, Pellegatta S, Mancuso P, Porrati P, Di Stefano AL, Ceroni M, Bertolini F, Finocchiaro G, Eoli M (2013) Prognostic value of CD109+ circulating endothelial cells in recurrent glioblastomas treated with bevacizumab and irinotecan. PLoS One 8:e74345. doi:10.1371/journal.pone.0074345

43. D'Souza-Schorey C, Clancy JW (2012) Tumor-derived microvesicles: shedding light on novel microenvironment modulators and prospective cancer biomarkers. Genes Dev 26:1287-1299. doi:10.1101/gad.192351.112

44. Dawson S-J, Tsui DWY, Murtaza M, Biggs H, Rueda OM, Chin S-F, Dunning MJ, Gale D, Forshew T, Mahler-Araujo B, Rajan S, Humphray S, Becq J, Halsall D, Wallis M, Bentley D, Caldas C, Rosenfeld N (2013) Analysis of circulating tumor DNA to monitor metastatic breast cancer. N Engl J Med 368:11991209. doi:10.1056/NEJMoa1213261

45. Elstner A, Stockhammer F, Nguyen-Dobinsky T-N, Nguyen QL, Pilgermann I, Gill A, Guhr A, Zhang T, von Eckardstein K, Picht T, Veelken J, Martuza RL, von Deimling A, Kurtz A (2011) Identification of diagnostic serum protein profiles of glioblastoma patients. J Neurooncol 102:71-80. doi:10.1007/ s11060-010-0284-8

46. Eoli M, Di Stefano A, Aquino D, Scotti A, Anghileri E, Cuppini L, Prodi E, Finocchiaro G, Bruzzone MG (2013) MC130072 Tumor perfusion during bevacizumab and irinotecan in recurrent glioblastoma: a multimodal approach. Eur J Cancer 49:S32. doi:10.1016/S0959-8049(13)70179-5

47. Fecci PE, Mitchell DA, Whitesides JF, Xie W, Friedman AH, Archer GE, Herndon JE, Bigner DD, Dranoff G, Sampson JH (2006) Increased regulatory T-cell fraction amidst a diminished CD4 compartment explains cellular immune defects in patients with malignant glioma. Cancer Res 66:3294-3302. doi:10.1158/0008-5472.CAN-05-3773

48. Fiano V, Trevisan M, Trevisan E, Senetta R, Castiglione A, Sacerdote C, Gillio-Tos A, De Marco L, Grasso C, Magistrello $\mathrm{M}$, Tondat $\mathrm{F}$, Rudà $\mathrm{R}$, Cassoni $\mathrm{P}$, Soffietti R, Merletti $\mathrm{F}$ (2014) MGMT promoter methylation in plasma of glioma patients receiving temozolomide. J Neurooncol 117:347-357. doi:10.1007/s11060-014-1395-4

49. Fine HA, Figg WD, Jaeckle K, Wen PY, Kyritsis AP, Loeffler JS, Levin VA, Black PM, Kaplan R, Pluda JM, Yung WK (2000) Phase II trial of the antiangiogenic agent thalidomide in patients with recurrent high-grade gliomas. J Clin Oncol 18:708-715

50. Forshew T, Murtaza M, Parkinson C, Gale D, Tsui DWY, Kaper F, Dawson S-J, Piskorz AM, Jimenez-Linan M, Bentley D, Hadfield J, May AP, Caldas C, Brenton JD, Rosenfeld N (2012) Noninvasive identification and monitoring of cancer mutations by targeted deep sequencing of plasma DNA. Sci Transl Med 4:136ra68. doi:10.1126/scitranslmed.3003726

51. Friedberg MH, Glantz MJ, Klempner MS, Cole BF, Perides G (1998) Specific matrix metalloproteinase profiles in the cerebrospinal fluid correlated with the presence of malignant astrocytomas, brain metastases, and carcinomatous meningitis. Cancer 82:923-930

52. Gállego Pérez-Larraya J, Paris S, Idbaih A, Dehais C, LaigleDonadey F, Navarro S, Capelle L, Mokhtari K, Marie Y, Sanson M, Hoang-Xuan K, Delattre J-Y, Mallet A (2014) Diagnostic and prognostic value of preoperative combined GFAP, IGFBP2 , and YKL-40 plasma levels in patients with glioblastoma. Cancer. doi:10.1002/cncr.28949

53. Garcia-Navarrete R, Garcia E, Arrieta O, Sotelo J (2010) Hepatocyte growth factor in cerebrospinal fluid is associated with mortality and recurrence of glioblastoma, and could be of prognostic value. J Neurooncol 97:347-351. doi:10.1007/ s11060-009-0037-8

54. Garnier D, Jabado N, Rak J (2013) Extracellular vesicles as prospective carriers of oncogenic protein signatures in adult and paediatric brain tumours. Proteomics 13:1595-1607. doi:10.1002/pmic. 201200360

55. Gautam P, Nair SC, Gupta MK, Sharma R, Polisetty RV, Uppin MS, Sundaram C, Puligopu AK, Ankathi P, Purohit AK, Chandak GR, Harsha HC, Sirdeshmukh R (2012) Proteins with altered levels in plasma from glioblastoma patients as revealed by iTRAQ-based quantitative proteomic analysis. PLoS One 7:e46153. doi:10.1371/journal.pone.0046153

56. Gerstner ER, Eichler AF, Plotkin SR, Drappatz J, Doyle CL, Xu L, Duda DG, Wen PY, Jain RK, Batchelor TT (2011) Phase I trial with biomarker studies of vatalanib (PTK787) in patients with newly diagnosed glioblastoma treated with enzyme inducing anti-epileptic drugs and standard radiation and temozolomide. J Neurooncol 103:325-332. doi:10.1007/ s11060-010-0390-7

57. Gilbert MR, Dignam JJ, Armstrong TS, Wefel JS, Blumenthal DT, Vogelbaum MA, Colman H, Chakravarti A, Pugh S, Won M, Jeraj R, Brown PD, Jaeckle KA, Schiff D, Stieber VW, Brachman DG, Werner-Wasik M, Tremont-Lukats IW, Sulman EP et al (2014) A randomized trial of bevacizumab for newly diagnosed glioblastoma. N Engl J Med 370:699-708. doi:10.1056/NEJMoa1308573

58. Gorlia T, Stupp R, Brandes AA, Rampling RR, Fumoleau P, Dittrich C, Campone MM, Twelves CC, Raymond E, Hegi ME, Lacombe D, van den Bent MJ (2012) New prognostic factors and calculators for outcome prediction in patients with recurrent glioblastoma: a pooled analysis of EORTC Brain Tumour Group phase I and II clinical trials. Eur J Cancer 48:1176-1184. doi:10.1016/j.ejca.2012.02.004 
59. Gousias K, Markou M, Arzoglou V, Voulgaris S, Vartholomatos G, Kostoula A, Voulgari P, Polyzoidis K, Kyritsis AP (2010) Frequent abnormalities of the immune system in gliomas and correlation with the WHO grading system of malignancy. J Neuroimmunol 226:136-142. doi:10.1016/j.jneuroim.2010.05.027

60. Gousias K, von Ruecker A, Voulgari P, Simon M (2013) Phenotypical analysis, relation to malignancy and prognostic relevance of ICOS $+\mathrm{T}$ regulatory and dendritic cells in patients with gliomas. $\mathbf{J}$ Neuroimmunol 264:84-90. doi:10.1016/j.jneuroim.2013.09.001

61. Greenfield JP, Jin DK, Young LM, Christos PJ, Abrey L, Rafii S, Gutin PH (2009) Surrogate markers predict angiogenic potential and survival in patients with glioblastoma multiforme. Neurosurgery 64:819-826. doi:10.1227/01.NEU.0000343742.06625. DB (discussion 826-827)

62. De Groot JF, Piao Y, Tran H, Gilbert M, Wu H-K, Liu J, Bekele BN, Cloughesy T, Mehta M, Robins HI, Lassman A, DeAngelis L, Camphausen K, Chen A, Yung W, Prados M, Wen PY, Heymach JV (2011) Myeloid biomarkers associated with glioblastoma response to anti-VEGF therapy with aflibercept. Clin Cancer Res 17:4872-4881. doi:10.1158/1078-0432.CCR-11-0271

63. Güttler A, Giebler M, Cuno P, Wichmann H, Keßler J, Ostheimer C, Söling A, Strauss C, Illert J, Kappler M, Vordermark D, Bache M (2013) Osteopontin and splice variant expression level in human malignant glioma: radiobiologic effects and prognosis after radiotherapy. Radiother Oncol 108:535-540. doi:10.1016/j.radonc.2013.06.036

64. Hegi ME, Diserens A-C, Gorlia T, Hamou M-F, de Tribolet N, Weller M, Kros JM, Hainfellner JA, Mason W, Mariani L, Bromberg JEC, Hau P, Mirimanoff RO, Cairncross JG, Janzer RC, Stupp R (2005) MGMT gene silencing and benefit from temozolomide in glioblastoma. N Engl J Med 352:997-1003. doi:10.1056/NEJMoa043331

65. Hoke M, Dieckmann K, Koppensteiner R, Schillinger M, Marosi C, Mlekusch W (2011) Prognostic value of plasma D-dimer levels in patients with glioblastoma multiformeresults from a pilot study. Wien Klin Wochenschr 123:199-203. doi:10.1007/s00508-011-1556-9

66. Holdhoff M, Yovino SG, Boadu O, Grossman SA (2013) Blood-based biomarkers for malignant gliomas. J Neurooncol 113:345-352. doi:10.1007/s11060-013-1144-0

67. Hormigo A, Gu B, Karimi S, Riedel E, Panageas KS, Edgar MA, Tanwar MK, Rao JS, Fleisher M, DeAngelis LM, Holland EC (2006) YKL-40 and matrix metalloproteinase-9 as potential serum biomarkers for patients with high-grade gliomas. Clin Cancer Res 12:5698-5704. doi:10.1158/1078-0432.CCR-06-0181

68. Husain H, Savage W, Grossman SA, Ye X, Burger PC, Everett A, Bettegowda C, Diaz LA, Blair C, Romans KE, Holdhoff M (2012) Pre- and post-operative plasma glial fibrillary acidic protein levels in patients with newly diagnosed gliomas. J Neurooncol 109:123-127. doi:10.1007/s11060-012-0874-8

69. Huttner HB, Janich P, Köhrmann M, Jászai J, Siebzehnrubl F, Blümcke I, Suttorp M, Gahr M, Kuhnt D, Nimsky C, Krex D, Schackert G, Löwenbrück K, Reichmann H, Jüttler E, Hacke W, Schellinger PD, Schwab S, Wilsch-Bräuninger M et al (2008) The stem cell marker prominin-1/CD133 on membrane particles in human cerebrospinal fluid offers novel approaches for studying central nervous system disease. Stem Cells 26:698705. doi: 10.1634/stemcells.2007-0639

70. Idbaih A, Omuro A, Ducray F, Hoang-Xuan K (2007) Molecular genetic markers as predictors of response to chemotherapy in gliomas. Curr Opin Oncol 19:606-611. doi:10.1097/ CCO.0b013e $3282 \mathrm{f} 075 \mathrm{f} 3$

71. Ilhan A, Gartner W, Neziri D, Czech T, Base W, Hörl WH, Wagner L (2009) Angiogenic factors in plasma of brain tumour patients. Anticancer Res 29:731-736
72. Ilhan-Mutlu A, Wagner L, Preusser M (2013) Circulating biomarkers of CNS tumors: an update. Biomark Med 7:267-285. doi:10.2217/bmm.13.12

73. Ilhan-Mutlu A, Wagner L, Widhalm G, Wöhrer A, Bartsch S, Czech T, Heinzl H, Leutmezer F, Prayer D, Marosi C, Base W, Preusser M (2013) Exploratory investigation of eight circulating plasma markers in brain tumor patients. Neurosurg Rev 36:4555. doi:10.1007/s10143-012-0401-6 (discussion 55-56)

74. Ilhan-Mutlu A, Wagner L, Wöhrer A, Furtner J, Widhalm G, Marosi C, Preusser M (2012) Plasma MicroRNA-21 concentration may be a useful biomarker in glioblastoma patients. Cancer Invest 30:615-621. doi:10.3109/07357907.2012.708071

75. Iliff JJ, Wang M, Liao Y, Plogg BA, Peng W, Gundersen GA, Benveniste H, Vates GE, Deane R, Goldman SA, Nagelhus EA, Nedergaard M (2012) A paravascular pathway facilitates CSF flow through the brain parenchyma and the clearance of interstitial solutes, including amyloid $\beta$. Sci Transl Med 4:147ra111. doi:10.1126/scitranslmed.3003748

76. Iwadate Y, Hayama M, Adachi A, Matsutani T, Nagai Y, Hiwasa T, Saeki N (2008) High serum level of plasminogen activator inhibitor-1 predicts histological grade of intracerebral gliomas. Anticancer Res 28:415-418

77. Iwamoto FM, Hottinger AF, Karimi S, Riedel E, Dantis J, Jahdi M, Panageas KS, Lassman AB, Abrey LE, Fleisher M, DeAngelis LM, Holland EC, Hormigo A (2011) Serum YKL-40 is a marker of prognosis and disease status in high-grade gliomas. Neuro Oncol 13:1244-1251. doi:10.1093/neuonc/nor117

78. Jain RK, Duda DG, Willett CG, Sahani DV, Zhu AX, Loeffler JS, Batchelor TT, Sorensen AG (2009) Biomarkers of response and resistance to antiangiogenic therapy. Nat Rev Clin Oncol 6:327-338. doi:10.1038/nrclinonc.2009.63

79. Jelkmann W (2001) Pitfalls in the measurement of circulating vascular endothelial growth factor. Clin Chem 47:617-623

80. Jung CS, Foerch C, Schänzer A, Heck A, Plate KH, Seifert V, Steinmetz H, Raabe A, Sitzer M (2007) Serum GFAP is a diagnostic marker for glioblastoma multiforme. Brain 130:33363341. doi:10.1093/brain/awm263

81. Khleif SN, Doroshow JH, Hait WN (2010) AACR-FDA-NCI cancer biomarkers collaborative consensus report: advancing the use of biomarkers in cancer drug development. Clin Cancer Res 16:3299-3318. doi:10.1158/1078-0432.CCR-10-0880

82. Khwaja FW, Nolen JDL, Mendrinos SE, Lewis MM, Olson JJ, Pohl J, Van Meir EG, Ritchie JC, Brat DJ (2006) Proteomic analysis of cerebrospinal fluid discriminates malignant and nonmalignant disease of the central nervous system and identifies specific protein markers. Proteomics 6:6277-6287. doi:10.1002/pmic.200600135

83. Khwaja FW, Reed MS, Olson JJ, Schmotzer BJ, Gillespie GY, Guha A, Groves MD, Kesari S, Pohl J, Van Meir EG (2007) Proteomic identification of biomarkers in the cerebrospinal fluid (CSF) of astrocytoma patients. J Proteome Res 6:559-570. doi:10.1021/pr060240z

84. Kikuchi K, Gotoh H, Kowada M (1987) Immunosuppressive acidic protein in patients with brain tumours: a preliminary report. Acta Neurochir (Wien) 86:42-49. doi:10.1007/BF01419503

85. Klement GL, Yip T-T, Cassiola F, Kikuchi L, Cervi D, Podust V, Italiano JE, Wheatley E, Abou-Slaybi A, Bender E, Almog N, Kieran MW, Folkman J (2009) Platelets actively sequester angiogenesis regulators. Blood 113:2835-2842. doi:10.1182/ blood-2008-06-159541

86. Koppers-Lalic D, Hackenberg M, Bijnsdorp IV, van Eijndhoven MAJ, Sadek P, Sie D, Zini N, Middeldorp JM, Ylstra B, de Menezes RX, Würdinger T, Meijer GA, Pegtel DM (2014) Nontemplated nucleotide additions distinguish the small rna composition in cells from exosomes. Cell Rep. 8:1-10. doi:10.1016/j. celrep.2014.08.027 
87. Krebs MG, Metcalf RL, Carter L, Brady G, Blackhall FH, Dive C (2014) Molecular analysis of circulating tumour cells-biology and biomarkers. Nat Rev Clin Oncol 11:129-144. doi:10.1038/ nrclinonc.2013.253

88. Kros JM, Mustafa DM, Dekker LJM, Sillevis Smitt PAE, Luider TM, Zheng P-P (2014) Circulating glioma biomarkers. Neuro Oncol. doi:10.1093/neuonc/nou207

89. Kumar DM, Thota B, Shinde SV, Prasanna KV, Hegde AS, Arivazhagan A, Chandramouli BA, Santosh V, Somasundaram K (2010) Proteomic identification of haptoglobin $\alpha 2$ as a glioblastoma serum biomarker: implications in cancer cell migration and tumor growth. J Proteome Res 9:5557-5567. doi:10.1021/pr1001737

90. Kuratsu J, Yoshizato K, Yoshimura T, Leonard EJ, Takeshima H, Ushio Y (1993) Quantitative study of monocyte chemoattractant protein-1 (MCP-1) in cerebrospinal fluid and cyst fluid from patients with malignant glioma. J Natl Cancer Inst 85:1836-1839

91. Lange RP, Everett A, Dulloor P, Korley FK, Bettegowda C, Blair C, Grossman SA, Holdhoff M (2014) Evaluation of eight plasma proteins as candidate blood-based biomarkers for malignant gliomas. Cancer Invest 32:423-429. doi:10.3109/07357907.2014.933237

92. Lavon I, Refael M, Zelikovitch B, Shalom E, Siegal T (2010) Serum DNA can define tumor-specific genetic and epigenetic markers in gliomas of various grades. Neuro Oncol 12:173180. doi:10.1093/neuonc/nop041

93. Leon SA, Shapiro B, Sklaroff DM, Yaros MJ (1977) Free DNA in the serum of cancer patients and the effect of therapy. Cancer Res 37:646-650

94. Lin Y, Jiang T, Zhou K, Xu L, Chen B, Li G, Qiu X, Jiang T, Zhang W, Song SW (2009) Plasma IGFBP-2 levels predict clinical outcomes of patients with high-grade gliomas. Neuro Oncol 11:468-476. doi:10.1215/15228517-2008-114

95. Lin Y, Wang J-F, Gao G-Z, Zhang G-Z, Wang F-L, Wang Y-J (2013) Plasma levels of tissue inhibitor of matrix metalloproteinase-1 correlate with diagnosis and prognosis of glioma patients. Chin Med J (Engl) 126:4295-4300

96. Liu B-L, Cheng J-X, Zhang W, Zhang X, Wang R, Lin H, Huo J-L, Cheng H (2010) Quantitative detection of multiple gene promoter hypermethylation in tumor tissue, serum, and cerebrospinal fluid predicts prognosis of malignant gliomas. Neuro Oncol 12:540-548. doi:10.1093/neuonc/nop064

97. Locasale JW, Melman T, Song S, Yang X, Swanson KD, Cantley LC, Wong ET, Asara JM (2012) Metabolomics of human cerebrospinal fluid identifies signatures of malignant glioma. Mol Cell Proteomics 11(M111):014688. doi:10.1074/ mcp.M111.014688

98. Lombardi G, Corona G, Farina P, Pambuku A, Bellu L, Della Puppa A, Fiduccia P, Bertorelle R, Paola Gardiman M, Toffoli GZV (2014) Diagnostic value of plasma and urinary 2-hydroxyglutarate to identify patients with IDH-mutated glioma. J Clin Oncol 32:5s (suppl; abstr 2037)

99. Louis DN, Ohgaki H, Wiestler OD, Cavenee WK, Burger PC, Jouvet A, Scheithauer BW, Kleihues P (2007) The 2007 WHO classification of tumours of the central nervous system. Acta Neuropathol 114:97-109. doi:10.1007/s00401-007-0243-4

100. Louis DN, Perry A, Burger P, Ellison DW, Reifenberger G, von Deimling A, Aldape K, Brat D, Collins VP, Eberhart C, FigarellaBranger D, Fuller GN, Giangaspero F, Giannini C, Hawkins C, Kleihues P, Korshunov A, Kros JM, Beatriz Lopes M et al (2014) International Society of Neuropathology-Haarlem consensus guidelines for nervous system tumor classification and grading. Brain Pathol 24:429-435. doi:10.1111/bpa.12171

101. Louis DN, Ohgaki H, Wiestler OD, Cavenee WK (2007) WHO classification of tumours of the central nervous system. IARC Press, Lyon

102. Lyubimova NV, Toms MG, Popova EE, Bondarenko YV, Krat VB, Kushlinskii NE (2011) Neurospecific proteins in the serum of patients with brain tumors. Bull Exp Biol Med 150:732-734

103. Ma R, Zhang G, Wang H, Lv H, Fang F, Kang X (2012) Downregulation of miR-544 in tissue, but not in serum, is a novel biomarker of malignant transformation in glioma. Oncol Lett 4:1321-1324. doi:10.3892/ol.2012.918

104. Macarthur KM, Kao GD, Chandrasekaran S, Alonso-Basanta M, Chapman C, Lustig RA, Wileyto EP, Hahn SM, Dorsey JF (2014) Detection of brain tumor cells in the peripheral blood by a telomerase promoter-based assay. Cancer Res 74:2152-2159. doi:10.1158/0008-5472.CAN-13-0813

105. Majchrzak-Celińska A, Paluszczak J, Kleszcz R, Magiera M, Barciszewska A-M, Nowak S, Baer-Dubowska W (2013) Detection of MGMT, RASSF1A, p15INK4B, and p14ARF promoter methylation in circulating tumor-derived DNA of central nervous system cancer patients. J Appl Genet 54:335-344. doi:10.1007/s13353-013-0149-x

106. Manterola L, Guruceaga E, Gállego Pérez-Larraya J, GonzálezHuarriz M, Jauregui P, Tejada S, Diez-Valle R, Segura V, Samprón N, Barrena C, Ruiz I, Agirre A, Ayuso A, Rodríguez J, González A, Xipell E, Matheu A, López de Munain A, Tuñón $\mathrm{T}$ et al (2014) A small noncoding RNA signature found in exosomes of GBM patient serum as a diagnostic tool. Neuro Oncol 16:520-527. doi:10.1093/neuonc/not218

107. Martens T, Matschke J, Müller C, Riethdorf S, Balabanov S, Westphal M, Heese O (2013) Skeletal spread of an anaplastic astrocytoma (WHO grade III) and preservation of histopathological properties within metastases. Clin Neurol Neurosurg 115:323-328. doi:10.1016/j.clineuro.2012.05.025

108. Martin-Villalba A, Okuducu AF, von Deimling A (2008) The evolution of our understanding on glioma. Brain Pathol 18:455463. doi:10.1111/j.1750-3639.2008.00136.x

109. Masui K, Cloughesy TF, Mischel PS (2012) Review: molecular pathology in adult high-grade gliomas: from molecular diagnostics to target therapies. Neuropathol Appl Neurobiol 38:271-291. doi:10.1111/j.1365-2990.2011.01238.x

110. Matsuura H, Nakazawa S (1985) Prognostic significance of serum alpha 1-acid glycoprotein in patients with glioblastoma multiforme: a preliminary communication. J Neurol Neurosurg Psychiatry 48:835-837

111. Mitchell PS, Parkin RK, Kroh EM, Fritz BR, Wyman SK, Pogosova-Agadjanyan EL, Peterson A, Noteboom J, O'Briant KC, Allen A, Lin DW, Urban N, Drescher CW, Knudsen BS, Stirewalt DL, Gentleman R, Vessella RL, Nelson PS, Martin DB et al (2008) Circulating microRNAs as stable blood-based markers for cancer detection. Proc Natl Acad Sci 105:1051310518. doi:10.1073/pnas.0804549105

112. Møller HG, Rasmussen AP, Andersen HH, Johnsen KB, Henriksen M, Duroux M (2013) A systematic review of microRNA in glioblastoma multiforme: micro-modulators in the mesenchymal mode of migration and invasion. Mol Neurobiol 47:131-144. doi:10.1007/s12035-012-8349-7

113. Muller C, Holtschmidt J, Auer M, Heitzer E, Lamszus K, Schulte A, Matschke J, Langer-Freitag S, Gasch C, Stoupiec M, Mauermann O, Peine S, Glatzel M, Speicher MR, Geigl JB, Westphal M, Pantel K, Riethdorf S (2014) Hematogenous dissemination of glioblastoma multiforme. Sci Transl Med 6:247ra101. doi:10.1126/scitranslmed.3009095

114. Murtaza M, Dawson S-J, Tsui DWY, Gale D, Forshew T, Piskorz AM, Parkinson C, Chin S-F, Kingsbury Z, Wong ASC, Marass F, Humphray S, Hadfield J, Bentley D, Chin TM, Brenton JD, Caldas C, Rosenfeld N (2013) Non-invasive analysis of acquired resistance to cancer therapy by sequencing of plasma DNA. Nature 497:108-112. doi:10.1038/nature12065

115. Nakamizo S, Sasayama T, Shinohara M, Irino Y, Nishiumi S, Nishihara M, Tanaka H, Tanaka K, Mizukawa K, Itoh T, 
Taniguchi M, Hosoda K, Yoshida M, Kohmura E (2013) GC/ MS-based metabolomic analysis of cerebrospinal fluid (CSF) from glioma patients. J Neurooncol 113:65-74. doi:10.1007/ s11060-013-1090-x

116. Nilsson RJA, Balaj L, Hulleman E, van Rijn S, Pegtel DM, Walraven M, Widmark A, Gerritsen WR, Verheul HM, Vandertop WP, Noske DP, Skog J, Würdinger T (2011) Blood platelets contain tumor-derived RNA biomarkers. Blood 118:3680-3683. doi:10.1182/blood-2011-03-344408

117. Noerholm M, Balaj L, Limperg T, Salehi A, Zhu LD, Hochberg FH, Breakefield XO, Carter BS, Skog J (2012) RNA expression patterns in serum microvesicles from patients with glioblastoma multiforme and controls. BMC Cancer 12:22. doi:10.1186/1471-2407-12-22

118. Olar A, Aldape KD (2014) Using the molecular classification of glioblastoma to inform personalized treatment. J Pathol 232:165-177. doi:10.1002/path.4282

119. Ostrom QT, Gittleman H, Liao P, Rouse C, Chen Y, Dowling J, Wolinsky Y, Kruchko C, Barnholtz-Sloan J (2014) CBTRUS statistical report: primary brain and central nervous system tumors diagnosed in the United States in 2007-2011. Neuro Oncol 16(Suppl 4):iv1-iv63. doi:10.1093/neuonc/nou223

120. Pantel K, Alix-Panabières C, Riethdorf S (2009) Cancer micrometastases. Nat Rev Clin Oncol 6:339-351. doi:10.1038/ nrclinonc.2009.44

121. Parsons DW, Jones S, Zhang X, Lin JC-H, Leary RJ, Angenendt P, Mankoo P, Carter H, Siu I-M, Gallia GL, Olivi A, McLendon R, Rasheed BA, Keir S, Nikolskaya T, Nikolsky Y, Busam DA, Tekleab H, Diaz LA et al (2008) An integrated genomic analysis of human glioblastoma multiforme. Science 321:1807-1812. doi:10.1126/science. 1164382

122. Patel AP, Tirosh I, Trombetta JJ, Shalek AK, Gillespie SM, Wakimoto H, Cahill DP, Nahed BV, Curry WT, Martuza RL, Louis DN, Rozenblatt-Rosen O, Suva ML, Regev A, Bernstein BE (2014) Single-cell RNA-seq highlights intratumoral heterogeneity in primary glioblastoma. Science 344:1396-1401. doi: $10.1126 /$ science. 1254257

123. Patrick Y, Wen SK (2008) Malignant gliomas in adults. N Engl J Med 359:1850. doi:10.1056/NEJMc086380 (author reply 1850)

124. Peles E, Lidar Z, Simon AJ, Grossman R, Nass D, Ram Z (2004) Angiogenic factors in the cerebrospinal fluid of patients with astrocytic brain tumors. Neurosurgery 55:562-568. doi:10.1227/01.NEU.0000134383.27713.9A

125. Phillips HS, Kharbanda S, Chen R, Forrest WF, Soriano RH, Wu TD, Misra A, Nigro JM, Colman H, Soroceanu L, Williams PM, Modrusan Z, Feuerstein BG, Aldape K (2006) Molecular subclasses of high-grade glioma predict prognosis, delineate a pattern of disease progression, and resemble stages in neurogenesis. Cancer Cell 9:157-173. doi:10.1016/j.ccr.2006.02.019

126. Preusser M (2014) Neuro-oncology: a step towards clinical blood biomarkers of glioblastoma. Nat Rev Neurol 10:681-682. doi:10.1038/nrneurol.2014.208

127. Quaranta M, Divella R, Daniele A, Di Tardo S, Venneri MT, Lolli I, Troccoli G (2007) Epidermal growth factor receptor serum levels and prognostic value in malignant gliomas. Tumori 93:275-280

128. Rafat N, Beck GC, Schulte J, Tuettenberg J, Vajkoczy P (2010) Circulating endothelial progenitor cells in malignant gliomas. $\mathrm{J}$ Neurosurg 112:43-49. doi:10.3171/2009.5.JNS081074

129. Restrepo L, Stafford P, Magee DM, Johnston SA (2011) Application of immunosignatures to the assessment of Alzheimer's disease. Ann Neurol 70:286-295. doi:10.1002/ana.22405

130. Reynés G, Vila V, Fleitas T, Reganon E, Font de Mora J, Jordá M, Martínez-Sales V (2013) Circulating endothelial cells and procoagulant microparticles in patients with glioblastoma: prognostic value. PLoS One 8:e69034. doi:10.1371/journal. pone. 0069034

131. Reynés G, Vila V, Martín M, Parada A, Fleitas T, Reganon E, Martínez-Sales V (2011) Circulating markers of angiogenesis, inflammation, and coagulation in patients with glioblastoma. J Neurooncol 102:35-41. doi:10.1007/s11060-010-0290-x

132. Rhodes CH, Honsinger C, Sorenson GD (1994) Detection of tumor-derived DNA in cerebrospinal fluid. J Neuropathol Exp Neurol 53:364-368

133. Ricard D, Idbaih A, Ducray F, Lahutte M, Hoang-Xuan K, Delattre J-Y (2012) Primary brain tumours in adults. Lancet 379:1984-1996. doi:10.1016/S0140-6736(11)61346-9

134. Risitano A, Beaulieu LM, Vitseva O, Freedman JE (2012) Platelets and platelet-like particles mediate intercellular RNA transfer. Blood 119:6288-6295. doi:10.1182/blood-2011-12-396440

135. Rohle D, Popovici-Muller J, Palaskas N, Turcan S, Grommes C, Campos C, Tsoi J, Clark O, Oldrini B, Komisopoulou E, Kunii K, Pedraza A, Schalm S, Silverman L, Miller A, Wang F, Yang H, Chen Y, Kernytsky A et al (2013) An inhibitor of mutant IDH1 delays growth and promotes differentiation of glioma cells. Science 340:626-630. doi:10.1126/science.1236062

136. Roth P, Wischhusen J, Happold C, Chandran PA, Hofer S, Eisele G, Weller M, Keller A (2011) A specific miRNA signature in the peripheral blood of glioblastoma patients. J Neurochem 118:449-457. doi:10.1111/j.1471-4159.2011.07307.x

137. Roux-Lombard P, Pagano S, Montecucco F, Satta N, Vuilleumier N (2013) Auto-antibodies as emergent prognostic markers and possible mediators of ischemic cardiovascular diseases. Clin Rev Allergy Immunol 44:84-97. doi:10.1007/ s12016-010-8233-Z

138. Roy R, Yang J, Moses MA (2009) Matrix metalloproteinases as novel biomarkers and potential therapeutic targets in human cancer. J Clin Oncol 27:5287-5297. doi:10.1200/ JCO.2009.23.5556

139. Nishikawa R, Saran F, Mason W, Wick W, Cloughesy TF, Henriksson R, Hilton M, Garcia J, Vogt T, Pallaud C, Chinot OL (2013) Biomarker (BM) evaluations in the phase III AVAglio study of bevacizumab (Bv) plus standard radiotherapy (RT) and temozolomide (T) for newly diagnosed glioblastoma (GBM). J Clin Oncol 31 (suppl; abstr 2023^)

140. Salkeni MA, Zarzour A, Ansay TY, McPherson CM, Warnick RE, Rixe O, Bahassi EM (2013) Detection of EGFRvIII mutant DNA in the peripheral blood of brain tumor patients. J Neurooncol 115:27-35. doi:10.1007/s11060-013-1209-0

141. Salmaggi A, Eoli M, Frigerio S, Ciusani E, Silvani A, Boiardi A (1999) Circulating intercellular adhesion molecule-1 (ICAM1), vascular cell adhesion molecule-1 (VCAM-1) and plasma thrombomodulin levels in glioblastoma patients. Cancer Lett 146:169-172

142. Sampath P, Weaver CE, Sungarian A, Cortez S, Alderson L, Stopa EG (2004) Cerebrospinal fluid (vascular endothelial growth factor) and serologic (recoverin) tumor markers for malignant glioma. Cancer Control 11:174-180

143. Saratsis AM, Yadavilli S, Magge S, Rood BR, Perez J, Hill DA, Hwang E, Kilburn L, Packer RJ, Nazarian J (2012) Insights into pediatric diffuse intrinsic pontine glioma through proteomic analysis of cerebrospinal fluid. Neuro Oncol 14:547-560. doi:10.1093/neuonc/nos067

144. Sato Y, Honda Y, Asoh T, Oizumi K, Ohshima Y, Honda E (1998) Cerebrospinal fluid ferritin in glioblastoma: evidence for tumor synthesis. J Neurooncol 40:47-50

145. Sawaya R, Cummins C, Smith B, Kornblith P (1985) Plasma fibronectin in patients with brain tumors. Neurosurgery. 16:161-165 
146. Schmidt C (2011) Larger companies dominate cancer companion diagnostic approvals. Nat Biotechnol 29:955-957. doi:10.1038/nbt1111-955

147. Schneider T, Sailer M, Ansorge S, Firsching R, Reinhold D (2006) Increased concentrations of transforming growth factor beta1 and beta2 in the plasma of patients with glioblastoma. $\mathrm{J}$ Neurooncol 79:61-65. doi:10.1007/s11060-005-9116-7

148. Schuhmann MU, Zucht HD, Nassimi R, Heine G, Schneekloth CG, Stuerenburg HJ, Selle H (2010) Peptide screening of cerebrospinal fluid in patients with glioblastoma multiforme. Eur J Surg Oncol 36:201-207. doi:10.1016/j.ejso.2009.07.010

149. Schwarzenbach H, Hoon DSB, Pantel K (2011) Cell-free nucleic acids as biomarkers in cancer patients. Nat Rev Cancer 11:426-437. doi:10.1038/nrc3066

150. Schwarzenbach H, Nishida N, Calin GA, Pantel K (2014) Clinical relevance of circulating cell-free microRNAs in cancer. Nat Rev Clin Oncol 11:145-156. doi:10.1038/nrclinonc.2014.5

151. Shao H, Chung J, Balaj L, Charest A, Bigner DD, Carter BS, Hochberg FH, Breakefield XO, Weissleder R, Lee H (2012) Protein typing of circulating microvesicles allows real-time monitoring of glioblastoma therapy. Nat Med 18:1835-1840. doi: $10.1038 / \mathrm{nm} .2994$

152. Shao N, Wang L, Xue L, Wang R, Lan Q (2014) Plasma miR454-3p as a potential prognostic indicator in human glioma. Neurol Sci. doi:10.1007/s10072-014-1938-7

153. Shnaper S, Desbaillets I, Brown DA, Murat A, Migliavacca E, Schluep M, Ostermann S, Hamou M-F, Stupp R, Breit SN, de Tribolet N, Hegi ME (2009) Elevated levels of MIC-1/GDF15 in the cerebrospinal fluid of patients are associated with glioblastoma and worse outcome. Int J Cancer 125:2624-2630. doi:10.1002/ijc. 24639

154. Siebzehnrubl FA, Reynolds BA, Vescovi A, Steindler DA, Deleyrolle LP (2011) The origins of glioma: E Pluribus Unum? Glia 59:1135-1147. doi:10.1002/glia.21143

155. Skog J, Würdinger T, van Rijn S, Meijer DH, Gainche L, SenaEsteves M, Curry WT, Carter BS, Krichevsky AM, Breakefield XO (2008) Glioblastoma microvesicles transport RNA and proteins that promote tumour growth and provide diagnostic biomarkers. Nat Cell Biol 10:1470-1476. doi:10.1038/ncb1800

156. Sottoriva A, Spiteri I, Piccirillo SGM, Touloumis A, Collins VP, Marioni JC, Curtis C, Watts C, Tavaré S (2013) Intratumor heterogeneity in human glioblastoma reflects cancer evolutionary dynamics. Proc Natl Acad Sci 110:4009-4014. doi:10.1073/ pnas. 1219747110

157. Sreekanthreddy P, Srinivasan H, Kumar DM, Nijaguna MB, Sridevi S, Vrinda M, Arivazhagan A, Balasubramaniam A, Hegde AS, Chandramouli BA, Santosh V, Rao MRS, Kondaiah V, Somasundaram K (2010) Identification of potential serum biomarkers of glioblastoma: serum osteopontin levels correlate with poor prognosis. Cancer Epidemiol Biomarkers Prev 19:1409-1422. doi:10.1158/1055-9965.EPI-09-1077

158. Strojnik T, Smigoc T, Lah TT (2014) Prognostic value of erythrocyte sedimentation rate and C-reactive protein in the blood of patients with glioma. Anticancer Res 34:339-347

159. Stupp R, Tonn J-C, Brada M, Pentheroudakis G (2010) Highgrade malignant glioma: ESMO Clinical Practice Guidelines for diagnosis, treatment and follow-up. Ann Oncol 21(Suppl 5):v190-v193. doi:10.1093/annonc/mdq187

160. Stupp R, Mason WP, van den Bent MJ, Weller M, Fisher B, Taphoorn MJB, Belanger K, Brandes AA, Marosi C, Bogdahn U, Curschmann J, Janzer RC, Ludwin SK, Gorlia T, Allgeier A, Lacombe D, Cairncross JG, Eisenhauer E, Mirimanoff RO (2005) Radiotherapy plus concomitant and adjuvant temozolomide for glioblastoma. N Engl J Med 352:987-996. doi:10.1056/ NEJMoa043330
161. Sturm D, Witt H, Hovestadt V, Khuong-Quang D-A, Jones DTW, Konermann C, Pfaff E, Tönjes M, Sill M, Bender S, Kool M, Zapatka M, Becker N, Zucknick M, Hielscher T, Liu X-Y, Fontebasso AM, Ryzhova M, Albrecht S et al (2012) Hotspot mutations in $\mathrm{H} 3 \mathrm{~F} 3 \mathrm{~A}$ and IDH1 define distinct epigenetic and biological subgroups of glioblastoma. Cancer Cell 22:425-437. doi:10.1016/j.ccr.2012.08.024

162. Sullivan JP, Nahed BV, Madden MW, Oliveira SM, Springer S, Bhere D, Chi AS, Wakimoto H, Rothenberg SM, Sequist LV, Kapur R, Shah K, Iafrate AJ, Curry WT, Loeffler JS, Batchelor TT, Louis DN, Toner M, Maheswaran S et al (2014) Brain tumor cells in circulation are enriched for mesenchymal gene expression. Cancer Discov. doi:10.1158/2159-8290.CD-14-0471

163. Taal W, Brandsma D, de Bruin HG, Bromberg JE, SwaakKragten AT, Smitt PA, van Es CA, van den Bent MJ (2008) Incidence of early pseudo-progression in a cohort of malignant glioma patients treated with chemoirradiation with temozolomide. Cancer 113:405-410. doi:10.1002/cncr.23562

164. Tabatabai G, Stupp R, van den Bent MJ, Hegi ME, Tonn JC, Wick W, Weller M (2010) Molecular diagnostics of gliomas: the clinical perspective. Acta Neuropathol 120:585-592. doi:10.1007/s00401-010-0750-6

165. Tabouret E, Boudouresque F, Barrie M, Matta M, Boucard C, Loundou A, Carpentier A, Sanson M, Metellus P, FigarellaBranger D, Ouafik L, Chinot O (2014) Association of matrix metalloproteinase 2 plasma level with response and survival in patients treated with bevacizumab for recurrent high-grade glioma. Neuro Oncol 16:392-399. doi:10.1093/neuonc/not226

166. Tanaka S, Louis DN, Curry WT, Batchelor TT, Dietrich J (2013) Diagnostic and therapeutic avenues for glioblastoma: no longer a dead end? Nat Rev Clin Oncol 10:14-26. doi:10.1038/ nrclinonc. 2012.204

167. Tanwar MK, Gilbert MR, Holland EC (2002) Gene expression microarray analysis reveals YKL-40 to be a potential serum marker for malignant character in human glioma. Cancer Res 62:4364-4368

168. Tektonidou MG, Ward MM (2011) Validation of new biomarkers in systemic autoimmune diseases. Nat Rev Rheumatol 7:708-717. doi:10.1038/nrrheum.2011.157

169. The Cancer Genome Atlas research Network (2008) Comprehensive genomic characterization defines human glioblastoma genes and core pathways. Nature 455:1061-1068. doi:10.1038/ nature 07385

170. Van Thuijl HF, Ylstra B, Würdinger T, van Nieuwenhuizen D, Heimans JJ, Wesseling P, Reijneveld JC (2013) Genetics and pharmacogenomics of diffuse gliomas. Pharmacol Ther 137:78-88. doi:10.1016/j.pharmthera.2012.09.002

171. Todaro L, Christiansen S, Varela M, Campodónico P, Pallotta MG, Lastiri J, Sacerdote de Lustig E, de Kier Bal, Joffé E, Puricelli L (2007) Alteration of serum and tumoral neural cell adhesion molecule (NCAM) isoforms in patients with brain tumors. J Neurooncol 83:135-144. doi:10.1007/s11060-006-9312-0

172. Tykocinski ES, Grant RA, Kapoor GS, Krejza J, Bohman L-E, Gocke TA, Chawla S, Halpern CH, Lopinto J, Melhem ER, O'Rourke DM (2012) Use of magnetic perfusion-weighted imaging to determine epidermal growth factor receptor variant III expression in glioblastoma. Neuro Oncol 14:613-623. doi:10.1093/neuonc/nos073

173. Unger EF, Goncalves L, Epstein SE, Chew EY, Trapnell CB, Cannon RO, Quyyumi AA (2000) Effects of a single intracoronary injection of basic fibroblast growth factor in stable angina pectoris. Am J Cardiol 85:1414-1419

174. Verhaak RGW, Hoadley KA, Purdom E, Wang V, Qi Y, Wilkerson MD, Miller CR, Ding L, Golub T, Mesirov JP, Alexe G, Lawrence M, O’Kelly M, Tamayo P, Weir BA, Gabriel S, 
Winckler W, Gupta S, Jakkula L et al (2010) Integrated genomic analysis identifies clinically relevant subtypes of glioblastoma characterized by abnormalities in PDGFRA, IDH1, EGFR, and NF1. Cancer Cell 17:98-110. doi:10.1016/j.ccr.2009.12.020

175. Vos MJ, Postma TJ, Martens F, Uitdehaag BMJ, Blankenstein MA, Vandertop WP, Slotman BJ, Heimans JJ (2004) Serum levels of S-100B protein and neuron-specific enolase in glioma patients: a pilot study. Anticancer Res 24:2511-2514

176. Wakabayashi T, Natsume A, Hatano H, Fujii M, Shimato S, Ito M, Ohno M, Ito S, Ogura M, Yoshida J (2009) P16 promoter methylation in the serum as a basis for the molecular diagnosis of gliomas. Neurosurgery 64:455-461. doi:10.1227/01. NEU.0000340683.19920.E3 (discussion 461-462)

177. Wang LG, Setlow RB (1989) Inactivation of O6-alkylguanineDNA alkyltransferase in HeLa cells by cisplatin. Carcinogenesis 10:1681-1684

178. Wang Q, Li P, Li A, Jiang W, Wang H, Wang J, Xie K (2012) Plasma specific miRNAs as predictive biomarkers for diagnosis and prognosis of glioma. J Exp Clin Cancer Res 31:97. doi:10.1186/1756-9966-31-97

179. Weller M, Felsberg J, Hartmann C, Berger H, Steinbach JP, Schramm J, Westphal M, Schackert G, Simon M, Tonn JC, Heese O, Krex D, Nikkhah G, Pietsch T, Wiestler O, Reifenberger G, von Deimling A, Loeffler M (2009) Molecular predictors of progression-free and overall survival in patients with newly diagnosed glioblastoma: a prospective translational study of the German Glioma Network. J Clin Oncol 27:5743-5750. doi:10.1200/JCO.2009.23.0805

180. Weller M, Stupp R, Hegi ME, van den Bent M, Tonn JC, Sanson M, Wick W, Reifenberger G (2012) Personalized care in neurooncology coming of age: why we need MGMT and $1 \mathrm{p} / 19 \mathrm{q}$ testing for malignant glioma patients in clinical practice. Neuro Oncol 14(Suppl 4):iv100-iv108. doi:10.1093/neuonc/nos206

181. Wen PY, Macdonald DR, Reardon DA, Cloughesy TF, Sorensen AG, Galanis E, Degroot J, Wick W, Gilbert MR, Lassman AB, Tsien C, Mikkelsen T, Wong ET, Chamberlain MC, Stupp R, Lamborn KR, Vogelbaum MA, van den Bent MJ, Chang SM (2010) Updated response assessment criteria for high-grade gliomas: response assessment in neuro-oncology working group. $\mathrm{J}$ Clin Oncol 28:1963-1972. doi:10.1200/JCO.2009.26.3541

182. Wesseling P, Kros JM, Jeuken JWM (2011) The pathological diagnosis of diffuse gliomas: towards a smart synthesis of microscopic and molecular information in a multidisciplinary context. Diagn Histopathol 17:486-494. doi:10.1016/j. mpdhp.2011.08.005

183. Wick W, Weller M, van den Bent M, Sanson M, Weiler M, von Deimling A, Plass C, Hegi M, Platten M, Reifenberger G (2014) MGMT testing-the challenges for biomarker-based glioma treatment. Nat Rev Neurol 10:372-385. doi:10.1038/ nrneurol.2014.100

184. Wiencke J, Accomando W, Zheng S (2012) Epigenetic biomarkers of T-cells in human glioma. Epigenetics. 7:1391-1402
185. Wood SL, Knowles MA, Thompson D, Selby PJ, Banks RE (2013) Proteomic studies of urinary biomarkers for prostate, bladder and kidney cancers. Nat Rev Urol 10:206-218. doi:10.1038/nrurol.2013.24

186. Wu W, Lamborn KR, Buckner JC, Novotny PJ, Chang SM, O'Fallon JR, Jaeckle KA, Prados MD (2010) Joint NCCTG and NABTC prognostic factors analysis for high-grade recurrent glioma. Neuro Oncol 12:164-172. doi:10.1093/neuonc/nop019

187. Wurdinger T, Deumelandt K, van der Vliet HJ, Wesseling P, de Gruijl TD (2014) Mechanisms of intimate and long-distance cross-talk between glioma and myeloid cells: how to break a vicious cycle. Biochim Biophys Acta Rev Cancer 1846:560575. doi:10.1016/j.bbcan.2014.10.003

188. Xu BJ, An QA, Srinivasa Gowda S, Yan W, Pierce LA, Abel TW, Rush SZ, Cooper MK, Ye F, Shyr Y, Weaver KD, Thompson RC (2012) Identification of blood protein biomarkers that aid in the clinical assessment of patients with malignant glioma. Int J Oncol 40:1995-2003. doi:10.3892/ijo.2012.1355

189. Yamaguchi Y, Shao Z, Sharif S, Du X-Y, Myles T, Merchant M, Harsh G, Glantz M, Recht L, Morser J, Leung LLK (2013) Thrombin-cleaved fragments of osteopontin are overexpressed in malignant glial tumors and provide a molecular niche with survival advantage. J Biol Chem 288:3097-3111. doi:10.1074/ jbc.M112.362954

190. Yang C, Wang C, Chen X, Chen S, Zhang Y, Zhi F, Wang J, Li L, Zhou X, Li N, Pan H, Zhang J, Zen K, Zhang C-Y, Zhang $C$ (2013) Identification of seven serum microRNAs from a genome-wide serum microRNA expression profile as potential noninvasive biomarkers for malignant astrocytomas. Int J Cancer 132:116-127. doi:10.1002/ijc.27657

191. Yoshida J, Wakabayashi T (1994) Tenascin in cerebrospinal fluid is a useful biomarker for the diagnosis of brain tumour. $\mathrm{J}$ Neurol Neurosurg Psychiatry 57:1212-1215

192. Yoshida S, Morii K (2000) Serum concentrations of soluble interleukin-2 receptor in patients with malignant brain tumors. J Surg Oncol 75:131-135

193. Zheng P-P, Hop WC, Luider TM, Sillevis Smitt PA, Kros JM (2007) Increased levels of circulating endothelial progenitor cells and circulating endothelial nitric oxide synthase in patients with gliomas. Ann Neurol 62:40-48. doi:10.1002/ana.21151

194. Zheng P-P, Luider TM, Pieters R, Avezaat CJJ, van den Bent MJ, Sillevis Smitt PA, Kros JM (2003) Identification of tumorrelated proteins by proteomic analysis of cerebrospinal fluid from patients with primary brain tumors. J Neuropathol Exp Neurol 62:855-862

195. Zucker S, Cao J (2005) Measurement of matrix metalloproteinases in serum of patients with melanoma: snarled in technical pitfalls. Clin Cancer Res 11:5069-5070. doi:10.1158/10780432.CCR-05-0774 